\title{
Solution Structure and Molecular Determinants of Hemoglobin Binding of the First NEAT Domain of IsdB in Staphylococcus aureus
}

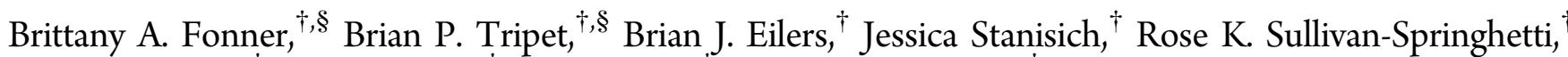 \\ Rebecca Moore, ${ }^{\dagger}$ Mengyao Liu, ${ }^{\dagger}$ Benfang Lei, ${ }^{\ddagger}$ and Valérie Copié ${ }^{*},^{\dagger}$
} ${ }^{\dagger}$ Department of Chemistry and Biochemistry, Montana State University, 103 Chemistry and Biochemistry Building, PO Box 173400,
Bozeman, Montana 59717-3400, United States
${ }^{\ddagger}$ Department of Immunology and Infectious Diseases, Montana State University, PO Box 173610, Bozeman, Montana 59717, United
States

Supporting Information

ABSTRACT: The human pathogen Staphylococcus aureus acquires heme iron from hemoglobin $(\mathrm{Hb})$ via the action of a series of iron-regulated surface determinant (Isd) proteins. The cell wall anchored Is $\mathrm{dB}$ protein is recognized as the predominant $\mathrm{Hb}$ receptor, and is comprised of two NEAr transporter (NEAT) domains that act in concert to bind, extract, and transfer heme from $\mathrm{Hb}$ to downstream Isd proteins. Structural details of the NEAT 2 domain of IsdB have been investigated, but the molecular coordination between NEAT 2 and NEAT 1 to extract heme from hemoglobin has yet to be characterized. To obtain a more complete understanding of IsdB structure and function, we have solved the $3 \mathrm{D}$ solution structure of the NEAT 1 domain of IsdB $\left(\mathrm{IsdB} \mathrm{N}^{\mathrm{N} 1}\right.$ ) spanning residues $125-272$ of the full-length protein by NMR. The structure reveals a canonical NEAT domain fold and has particular structural similarity to the NEAT 1 and NEAT 2 domains of IsdH, which also interact with $\mathrm{Hb}^{\mathrm{B}}$. IsdB $\mathrm{B}^{\mathrm{N} 1}$ is also comprised of a short N-terminal helix, which has not been previously observed in other NEAT domain structures. Interestingly, the $\mathrm{Hb}$ binding region (loop 2 of $\mathrm{IsdB}^{\mathrm{N} 1}$ ) is disordered in solution. Analysis of $\mathrm{Hb}$ binding demonstrates that IsdB $\mathrm{B}^{\mathrm{N} 1}$ can bind metHb weakly and the affinity of this interaction is further increased by the presence of IsdB linker domain. IsdB ${ }^{\mathrm{N} 1}$ loop 2 variants reveal that phenylalanine 164 (F164) of IsdB is necessary for $\mathrm{Hb}$ binding and rapid heme transfer from metHb to IsdB. Together, these findings provide a structural role for $\mathrm{IsdB}^{\mathrm{N} 1}$ in enhancing the rate of extraction of metHb heme by the IsdB NEAT 2 domain.

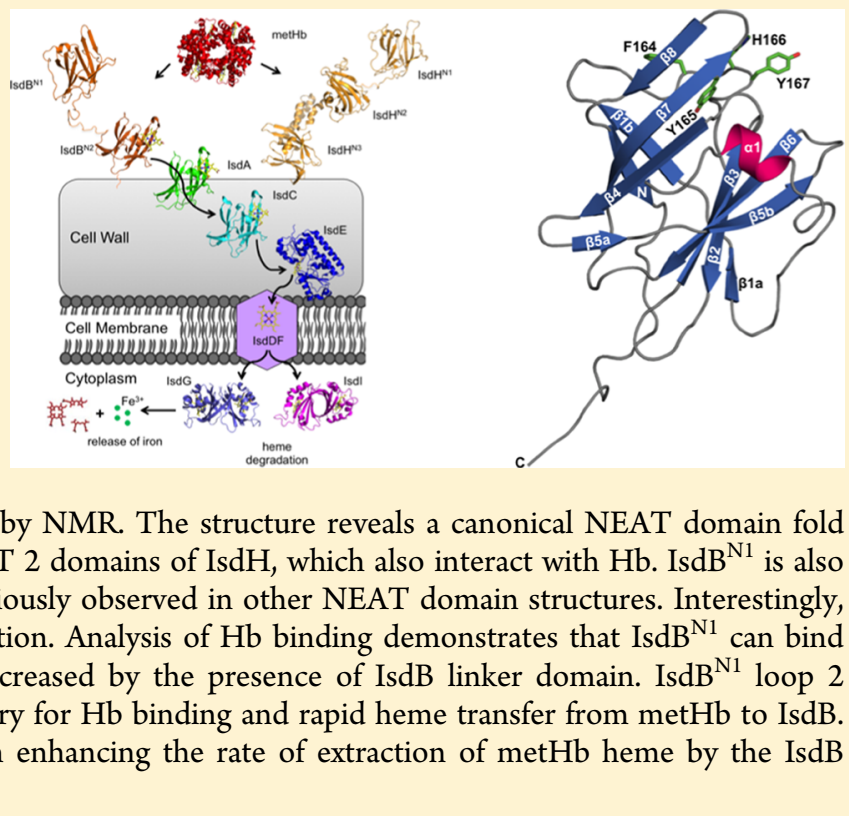

$\mathrm{T}$ he Gram-positive bacterium and opportunistic pathogen Staphylococcus aureus causes skin and life-threatening systemic infections in mammals. ${ }^{1}$ Critical to $S$. aureus growth, survival, and virulence is its ability to capture iron from its host. ${ }^{2}$ In mammals, the largest repository of iron is present in complex with protoporphyrin (heme) in hemoglobin ( $\mathrm{Hb})$. To capture and assimilate this heme-bound iron form, S. aureus has specifically optimized a series of nine iron-regulated surface determinant (Isd) proteins, denoted IsdA through IsdI.

Heme capture from $\mathrm{Hb}$ is accomplished by IsdB and IsdH that are anchored at the cell surface of $S$. aureus. Is $\mathrm{dB}$ preferentially captures heme from $\mathrm{Hb}$, whereas $\mathrm{IsdH}$ can capture heme from both $\mathrm{Hb}$ and the $\mathrm{Hb}$-Haptoglobin complex. $^{3,4}$ The acquired heme is subsequently transferred through the cell wall via a relay system of proteins exhibiting different affinities for heme and involves heme transfer from Is $\mathrm{dB}$ to IsdA and IsdC, which in turn relay heme to IsdE, the lipoprotein component of the ATP-binding cassette (ABC) transporter IsdEDF., ${ }^{3,5}$ From there, heme is transported across the cytoplasmic membrane by action of this $\mathrm{ABC}$ transporter system and oxidized in the cytoplasm by IsdG and IsdI to release iron from heme for cellular use in $S$. aureus. ${ }^{3,6,7}$

The $\mathrm{Hb}$ receptors IsdB and $\mathrm{IsdH}$ are comprised of two and three NEAr transporter (NEAT) domains, respectively, ${ }^{8,9}$ which enable them to rapidly acquire heme from $\mathrm{Hb}$. The structurally conserved NEAT domain is comprised of $\sim 120$ amino acids and adopts a characteristic immunoglobulin-like $\beta$ sandwich fold. ${ }^{9-15}$ The single NEAT domains of IsdA and IsdC, and the C-terminal NEAT domains of IsdB and IsdH have been shown to bind heme, ${ }^{10-14}$ and are comprised of a hydrophobic heme-binding site which envelops the heme within the proteins by a 6 -stranded antiparallel $\beta$-sheet on one side and a short $\alpha$-helix of the other side. ${ }^{16}$ A conserved YXXXY motif in the heme binding pocket of these NEAT domains, where one tyrosine binds the iron and the other tyrosine is involved in hydrogen-bonding to the axial tyrosine,

Received: April 29, 2014

Revised: $\quad$ May 27, 2014

Published: May 28, 2014 
appears to be key for heme binding, as other NEAT domains lacking this motif do not bind heme. ${ }^{10-13}$ However, in the crystal structure of IsdB-N2, two axial ligands consisting of a conserved tyrosine (Y440) and methionine (M362) coordinate heme in the protein heme binding pocket. ${ }^{14}$ The Met-Tyr axial coordination of IsdB-N2 is unique in heme iron binding proteins. The conserved Y440 is important for heme binding, but M362 is necessary for heme transfer to IsdA. The unique iron coordination of IsdB is predicted to be important for its unique role as a $\mathrm{Hb}$ receptor and initiator of heme import by the Isd pathway. ${ }^{14}$

However, the NEAT domains have evolved different functions, even within the same protein: IsdB and IsdH are modular proteins that include multiple NEAT domains, two and three, respectively, and their N-terminal NEAT domains, IsdB-N1, IsdH-N1, and IsdH-N2, do not bind heme and are instead involved in protein-protein interactions. ${ }^{9,17}$

Recent studies have shown that inactivation of the is $d B$ gene, but not isdH, significantly decreases hemoglobin binding and impairs the ability of $S$. aureus to utilize hemoglobin as an iron source. ${ }^{18}$ Furthermore, specific mutations within IsdB $\mathrm{Hb}$ binding domain resulted in a significant reduction in virulence of $S$. aureus variants. ${ }^{18}$ Thus, IsdB appears to be the predominant $\mathrm{Hb}$-binding receptor for heme acquisition by $S$. aureus.

IsdB is comprised of five protein segments: NEAT 1 (residues 145-270, IsdB ${ }^{\mathrm{N} 1}$ ), NEAT 2 (residues 338-458, IsdB ${ }^{\mathrm{N} 2}$ ), a linker region between $\mathrm{N} 1$ and $\mathrm{N} 2$ (residues 271-337), an Nterminal segment (residues 40 to 144), and a C-terminal segment (residues 459-613). The $\mathrm{N}$-terminal region contains a secretion signal motif (residues 1-39) for protein translocation to the cell wall, and the C-terminal segment contains a Cterminal membrane-anchoring LPXTG motif and a highly charged C-terminal residue stretch (residues 614-643), enabling protein anchoring to the cell wall via sortase $\mathrm{A}$ activity. ${ }^{9}$ IsdB $^{\mathrm{N} 2}$ is the heme-binding domain of $\mathrm{IsdB},{ }^{19}$ while the N-terminal segment and $\mathrm{IsdB}^{\mathrm{N1}}$ are required for the rapid kinetics of the methemoglobin (metHb)/IsdB reaction (ref 20 and $\mathrm{Zhu}$ et al., manuscript under review)). IsdB linker region between $\mathrm{N} 1$ and $\mathrm{N} 2$ drives the equilibrium of the metHb/IsdB reaction, whereas IsdB's C-terminal segment is not directly involved in the heme assimilation reaction ( $\mathrm{Zhu}$ et al., manuscript under review). These data strongly suggest that, except for the IsdB's C-terminal region, all other protein segments of IsdB are necessary and act in concert for rapid and efficient heme capture from metHb.

Initial studies demonstrated that IsdB N1-linker-N2 (residues 145-458) acquires heme from metHb slowly in a reaction that reaches almost full transfer upon equilibrium (Zhu et al., manuscript under review). We found that addition of amino acids $125-144$ to an IsdB N1-linker-N2 protein fragment stabilizes the protein construct while resulting in a comparable rate of heme transfer from metHb ( $\mathrm{Zhu}$ et al., manuscript under review). This indicates that the region encompassing amino acids 125-144, while not critical for the rapid kinetics of the metHb/IsdB reaction, may play an important structural role for IsdB. In the present study, IsdB ${ }^{\mathrm{N} 1}$ is thus denoted as the protein fragment spanning amino acid residues $125-272$. To initiate detailed structural studies of IsdB and to identify key residues interacting with metHb, we have solved the three-dimensional (3D) structure of $\mathrm{IsdB}^{\mathrm{N} 1}$ in solution. We investigated which residues of $\mathrm{IsdB}^{\mathrm{N} 1}$ are important mediators of $\mathrm{IsdB}^{\mathrm{N1}}$ :metHb protein-protein inter- actions using $2 \mathrm{D}{ }^{1} \mathrm{H}-{ }^{15} \mathrm{~N}$ correlation HSQC NMR experiments and by monitoring amide ${ }^{1} \mathrm{H} /{ }^{15} \mathrm{~N}$ chemical shift changes. Potentially crucial residues of $\mathrm{IsdB}^{\mathrm{N} 1}$ identified from NMR were further investigated using site-directed mutagenesis and in vitro heme transfer experiments. Results from these studies indicate that F164, and to a lesser extent $\mathrm{Y} 167$, of IsdB are important mediators of $\mathrm{IsdB}^{\mathrm{N} 1} /$ metHb interactions and play a key role in the rapid kinetics of heme transfer from metHb to IsdB. Taken together, our findings provide a structural and biochemical basis for the role of $\mathrm{IsdB}^{\mathrm{N1}}$ in enhancing the rate of extraction of metHb heme by the IsdB N2 domain.

\section{EXPERIMENTAL PROCEDURES}

DNA Cloning, Protein Expression, and Purification of IsdB ${ }^{\mathrm{N} 1}$ and IsdB ${ }^{\mathrm{N} 1}$ Variants. DNA cloning of IsdB NEAT 1 domain $\left(\mathrm{IsdB}^{\mathrm{N} 1}\right)$ encompassing residues Leu125 to Asp272 of IsdB was accomplished as previously described. ${ }^{21}$ DNA constructs encoding IsdB amino acid stretches Leu125Asn458 (referred to as IsdB ${ }^{\text {N1-L-N2 }}$ ), Leu125-Asn339 $\left(\right.$ IsdB $\left.^{\text {N1-L }}\right)$, Glu271-Asn458 (IsdB $\left.{ }^{\mathrm{L}-\mathrm{N} 2}\right)$, Glu304-Asn458 $\left(\mathrm{IsdB}^{35 \mathrm{LN} 2}\right)$, Lys319-Asn458 ( IsdB $\left.^{20 \mathrm{LN} 2}\right)$, and Asn339Asn458 (IsdB ${ }^{\mathrm{N} 2}$ ) were amplified using PCR from a pET-21d plasmid containing the is $d b$ gene encoding residues $40-613$ of IsdB as described in ref 3. DNA cloning of IsdH NEAT1 $\left(\mathrm{IsdH}^{\mathrm{N} 1}\right.$, residues Ala86-Leu229) and NEAT2 ( $\mathrm{IsdH}^{\mathrm{N} 2}$, residues Gln321-Asn464) was amplified by PCR from S. aureus strain ATCC 6538 genomic DNA. The PCR products were ligated into pET-46 Ek/LIC (Novagen) plasmid. pET46-DNA vectors encoding $\mathrm{IsdB}^{\mathrm{N} 1}-\mathrm{F} 164 \mathrm{D}$, IsdB ${ }^{\mathrm{N} 1}-\mathrm{Y} 167 \mathrm{D}$, IsdB ${ }^{\mathrm{N} 1 L N 2}$ F164D, IsdB ${ }^{\mathrm{N} 1 \mathrm{LN} 2}-\mathrm{F} 164 \mathrm{~A}$, IsdB ${ }^{\mathrm{N1LN2}}-\mathrm{Y} 167 \mathrm{D}$, and $\mathrm{IsdB}^{\mathrm{N} 1 \mathrm{LN} 2}$ F164D/Y167D protein variants were generated using the QuikChange Lightening (Agilent Technologies) site directed mutagenesis kit using wild type $\mathrm{IsdB}^{\mathrm{N1}}-\mathrm{pET} 46$ or $\mathrm{IsdB}^{\mathrm{N1}-\mathrm{L}-\mathrm{N} 2}$ pET46 vector as the starting template. All constructs were confirmed by Sanger sequencing and include the amino acids MAHHHHHHVDDDDKM added to the $\mathrm{N}$-terminus of the Is $\mathrm{dB}$ protein sequences.

Protein expression was carried out as in Fonner et al. ${ }^{21}$ To produce unlabeled proteins, Escherichia coli BL21(DE3) cells transformed with plasmids containing is $d B$ fragments were grown in $\mathrm{LB}$ medium to an $\mathrm{OD}_{600 \mathrm{~nm}}$ reading of 0.6 , upon which $1 \mathrm{mM}$ IPTG was added to induce protein expression, and cells were grown for an additional $6 \mathrm{~h}$. To produce uniformly ${ }^{15} \mathrm{~N}$ or ${ }^{15} \mathrm{~N} /{ }^{13} \mathrm{C}$-labeled IsdB proteins, BL21(DE3) E. coli cells transformed with the respective IsdB pET46 plasmids were grown in M9 minimal media supplemented with ${ }^{15} \mathrm{NH}_{4} \mathrm{Cl}$ $(1.5 \mathrm{~g} / \mathrm{L})$, or ${ }^{15} \mathrm{NH}_{4} \mathrm{Cl}$ and ${ }^{13} \mathrm{C}$-labeled-glucose $(3.0 \mathrm{~g} / \mathrm{L})$ (Cambridge Isotopes) as the sole nitrogen and carbon sources, respectively. Cells were grown to an $\mathrm{OD}_{600 \mathrm{~nm}}$ reading of 0.6 , upon which $1 \mathrm{mM}$ IPTG was added to induce ${ }^{15} \mathrm{~N}$ or ${ }^{15} \mathrm{~N} /{ }^{13} \mathrm{C}$ labeled protein expression, and cells grown for an additional 10 h. Cells were harvested by centrifugation at $4000 \mathrm{~g}$ for $15 \mathrm{~min}$, and resulting cell pellets stored at $-20{ }^{\circ} \mathrm{C}$ until further use. Cells were thawed and resuspended in lysis buffer $(20 \mathrm{mM}$ Tris, $500 \mathrm{mM} \mathrm{NaCl}, 50 \mathrm{mM} \mathrm{Na}_{2} \mathrm{HPO}_{4} / \mathrm{NaH}_{2} \mathrm{PO}_{4}, 10 \mathrm{mM}$ imidazole, $\mathrm{pH}$ 8) with freshly prepared $0.1 \mathrm{mM}$ PMSF and lysed using an M-110L microfluidizer instrument (Microfluidics). The lysate was clarified by centrifugation at $12000 \mathrm{~g}$ for $20 \mathrm{~min}$ at $4{ }^{\circ} \mathrm{C}$, and the supernatant applied to a nickel affinity chromatography column containing $5 \mathrm{~mL}$ bed volume of HisPur Ni-NTA Resin (Thermo Scientific). The column was washed with $2 \times$ the bed volume of lysis buffer and eluted with the same buffer containing $250 \mathrm{mM}$ imidazole. Protein- 
containing fractions were pooled and dialyzed against $20 \mathrm{mM}$ TrisHCl buffer, $\mathrm{pH}$ 8.0. Protein concentration was established by measuring the absorbance at $280 \mathrm{~nm}\left(\mathrm{OD}_{280 \mathrm{~nm}}\right)$ and an extinction coefficient $\varepsilon$ of $18910 \mathrm{M}^{-1} \mathrm{~cm}^{-1}$, protein purity assessed by SDS-PAGE, and protein molecular mass confirmed with mass spectrometry using MS instruments of the Proteomics and Metabolomics Mass Spectrometry Facility of Montana State University.

NMR Spectroscopy. Multidimensional (2D and 3D) heteronuclear $\left({ }^{1} \mathrm{H},{ }^{15} \mathrm{~N},{ }^{13} \mathrm{C}\right)$ NMR spectra were recorded on a $1 \mathrm{mM} \mathrm{IsdB}{ }^{\mathrm{N} 1}$ protein solution containing $50 \mathrm{mM}$ sodium phosphate, $400 \mathrm{mM}$ sodium chloride, $1.0 \mathrm{mM}$ EDTA, $0.1 \mathrm{mM}$ PMSF, and $0.01 \%$ sodium azide, at $\mathrm{pH} 6.8$, in either $95 \% \mathrm{H}_{2} \mathrm{O}$ / $5 \% \mathrm{D}_{2} \mathrm{O}$ or $100 \% \mathrm{D}_{2} \mathrm{O}$ (for acquisition of $3 \mathrm{D}{ }^{13} \mathrm{C}$-edited ${ }^{1} \mathrm{H}-{ }^{1} \mathrm{H}$ TOCSY and ${ }^{13} \mathrm{C}$-edited ${ }^{1} \mathrm{H}-{ }^{1} \mathrm{H}-\mathrm{NOESY}$ NMR spectra) on a four-channel Bruker AVANCE III 600 spectrometer equipped with a TCI NMR cryoprobe at $298 \mathrm{~K}\left(25^{\circ} \mathrm{C}\right)$. Extracted backbone and side chain resonance assignments are reported in ref 21 and have been deposited in the BMRB as entry 19056. For hydrogen/deuterium $\left({ }^{1} \mathrm{H} /{ }^{2} \mathrm{H}\right)$ solvent exchange experiments, $500 \mu \mathrm{L}$ of a $1 \mathrm{mM}{ }^{15} \mathrm{~N}$-labeled-IsdB ${ }^{\mathrm{N} 1}$ solution previously lyophilized was resuspended in $500 \mu \mathrm{L}$ of $100 \% \mathrm{D}_{2} \mathrm{O}$ and $2 \mathrm{D}{ }^{1} \mathrm{H}-{ }^{15} \mathrm{~N}$ correlation HSQC spectra ${ }^{22}$ collected at subsequent times. To ensure that the $\mathrm{IsdB}^{\mathrm{N} 1}$ protein was unaffected by the lyophilization process, a control experiment was performed whereby another protein sample was lyophilized and resuspended in $\mathrm{H}_{2} \mathrm{O}$. The resulting $2 \mathrm{D}$ ${ }^{1} \mathrm{H}-{ }^{15} \mathrm{~N}$ correlation HSQC NMR spectrum was identical to that of unlyophilized ${ }^{15} \mathrm{~N}$-labeled $\mathrm{IsdB}^{\mathrm{N} 1}$. In addition, 2D CLEANEX-PM NMR experiments ${ }^{23}$ were performed to identify amide hydrogens undergoing fast chemical exchange with solvent. All data were processed and analyzed with NMRPipe $^{24}$ and Sparky ${ }^{25}$ software.

NMR Protein Structure Calculations. Interproton NOE assignments were determined from analysis of $3 \mathrm{D}{ }^{15} \mathrm{~N}$-edited ${ }^{1} \mathrm{H}-{ }^{1} \mathrm{H}$ NOESY (NOE mixing period $\tau_{\mathrm{m}}=100 \mathrm{~ms}$ ) and 3D ${ }^{13} \mathrm{C}$-edited ${ }^{1} \mathrm{H}-{ }^{1} \mathrm{H}$ NOESY $\left(\tau_{\mathrm{m}}=100 \mathrm{~ms}\right)$ spectra. Assignments of NOE resonances were performed using a combination of manual inspection and automated NOE assignment using the UNIO'10 Version 2.0.2 software. ${ }^{26,27}$ Hydrogen bond restraints were identified from $\mathrm{NH}$ signals protected from ${ }^{1} \mathrm{H} /{ }^{2} \mathrm{H}$ solvent exchange. Backbone $\Phi$ and $\Psi$ dihedral angles constraints were derived from ${ }^{1} \mathrm{H}_{\alpha}{ }^{13} \mathrm{C}_{\alpha}$ and ${ }^{13} \mathrm{C}_{\beta}$ chemical shift data using the program TALOS $+{ }^{28}$ For the final set of protein structure calculations, 200 structures of $\mathrm{IsdB}^{\mathrm{N} 1}$ were generated with CYANA 2.1 using CYANA's standard simulated annealing protocol $^{27,29}$ and 40 structures with the lowest residual target functions were selected for water refinement in AMBER9 $9^{30}$ using the AMPS-NMR web portal ${ }^{31}$ and a standard restrained molecular dynamics protocol implemented within the AMBER99SB force field, a generalized Born model, and a $10 \AA$ TIP3P water box. ${ }^{31}$ From the set of 40 structures, $20 \mathrm{IsdB}^{\mathrm{N} 1}$ structures with lowest conformational energy and no experimental distance and dihedral angle constraints violations greater than $0.5 \AA$ or $5^{\circ}$, respectively, were selected to generate a final ensemble of low conformational energy $\mathrm{IsdB}^{\mathrm{N1}}$ protein structures. The overall quality of each $\mathrm{IsdB}^{\mathrm{N} 1}$ structure was assessed using PROCHECK-NMR, ${ }^{32}$ MolProbity, ${ }^{33}$ Verify $3 \mathrm{D},{ }^{34}$ and the protein structure validation suite (PSVS) software. ${ }^{35}$ The 20 conformers of Is $\mathrm{dB}^{\mathrm{N} 1}$ have been deposited in the protein data bank as PDB ID code 2MOQ. Protein structure figures were prepared using the PYMOL graphics program. ${ }^{36}$ Structural homology was identified with the DALI server, $^{37}$ and the structural superposition of Isd protein structural homologues was accomplished using the SSM superposition module of the Coot software. ${ }^{38}$

Size-Exclusion Chromatography. MetHb and Isd proteins singly or as a 1:6 molar mixture (metHb $(20 \mu \mathrm{M})$, subunit molecular weight of $16125 \mathrm{Da}$ and Isd protein (120 $\mu \mathrm{M})$ ) were equilibrated in $20 \mathrm{mM} \mathrm{NaH} \mathrm{PO}_{4}, 150 \mathrm{mM} \mathrm{NaCl}$, $\mathrm{pH} 7$ buffer at room temperature for $30 \mathrm{~min}$. A $50 \mu \mathrm{L}$ aliquot of the sample was loaded onto a high-performance size exclusion column, Superdex $75(1 \times 30 \mathrm{~cm})$ equilibrated in the same buffer at a flow rate of $0.4 \mathrm{~mL} / \mathrm{min}$ and ambient temperature. Each chromatogram was recorded using wavelengths of 230 , 280 , and $406 \mathrm{~nm}$. To specifically display the elution profile of metHb, only $406 \mathrm{~nm}$ chromatograms are shown in Figure 5. To calculate the change in molecular mass for each complex, the elution volume was compared to a standard curve generated from known proteins eluted under the same conditions.

NMR Studies of metHb Binding to IsdB ${ }^{\mathrm{N} 1}$. Binding of $\mathrm{IsdB}^{\mathrm{N} 1}$ to methemoglobin (metHb) was investigated using $2 \mathrm{D}$ ${ }^{1} \mathrm{H}-{ }^{15} \mathrm{~N}$ correlation HSQC $\mathrm{NMR}^{22}$ experiments recorded at $298 \mathrm{~K}$. Freshly purified ${ }^{15} \mathrm{~N}$-labeled $\mathrm{IsdB}^{\mathrm{N} 1}$ protein was dialyzed into NMR buffer ( $50 \mathrm{mM}$ sodium phosphate, $100 \mathrm{mM}$ sodium chloride, $1 \mathrm{mM}$ EDTA, $0.1 \mathrm{mM}$ PMSF, $0.01 \%$ sodium azide at $\mathrm{pH} 6.8)$ to which $5 \%(\mathrm{v} / \mathrm{v}) \mathrm{D}_{2} \mathrm{O}$ was added, and the solution concentrated to $0.5 \mathrm{mM}$ final protein concentration. A metHb stock solution was prepared by dissolving $8 \mathrm{mg}$ of lyophilized human metHb (Sigma) in $10 \mathrm{~mL}$ of NMR buffer followed by dialysis against $2 \times 1 \mathrm{~L} \mathrm{NMR}$ buffer. The solution was concentrated using a $10 \mathrm{kDa}$ (MWCO) centrifugal spin concentrator to a protein concentration of $0.5 \mathrm{mM}(\alpha \beta$ dimer, MW 32000$)$. Production of metHb:IsdB ${ }^{\mathrm{N} 1}$ NMR samples was accomplished by mixing $500 \mu \mathrm{L}$ of the $0.5 \mathrm{mM}$ human metHb stock solution with $0-1500 \mu \mathrm{L}$ of the $0.5 \mathrm{mM}$ ${ }^{15} \mathrm{~N}$-labeled $\mathrm{IsdB}^{\mathrm{N} 1}$ stock solution. The resulting protein mixtures were concentrated back to a $500 \mu \mathrm{L}$ volume, equilibrated for $30 \mathrm{~min}$, and then analyzed by NMR. 2D ${ }^{1} \mathrm{H}-{ }^{15} \mathrm{~N}$ correlation HSQC spectra were recorded at metHb:IsdB ${ }^{\mathrm{N} 1}$ protein ratios of $1: 0.5,1: 0.75,1: 1,1: 1.5,1: 2$, and $1: 3$. Competition experiments were carried out by adding progressive amounts of non-isotopically labeled $\mathrm{IsdB}^{\mathrm{N} 1}(0.25-$ $1.35 \mathrm{mM}$ ) to a $0.5 \mathrm{mM}$ equal molar metHb: ${ }^{15} \mathrm{~N}-\mathrm{IsdB}^{\mathrm{N} 1}$ sample solution, followed by the recording of resulting $2 \mathrm{D}{ }^{1} \mathrm{H}-{ }^{15} \mathrm{~N}$ correlation HSQC spectra. $\mathrm{Hb}$ binding studies of $\mathrm{IsdB}^{\mathrm{N} 1}$ variants as monitored by $2 \mathrm{D}{ }^{1} \mathrm{H}-{ }^{15} \mathrm{~N}$ correlation HSQC NMR experiments were conducted in a similar manner.

Preparation of Apo-IsdB Proteins for Heme Transfer Experiments. Apo-IsdB proteins, used in in vitro heme transfer experiments, were prepared using the methyl ethyl ketone heme extraction method as reported in ref 39. Briefly, a $5 \mathrm{~mL}$ aliquot of a $0.2 \mathrm{mg} / \mathrm{mL}$ IsdB protein solution dissolved in $20 \mathrm{mM}$ TrisHCl, $\mathrm{pH} 8$, was adjusted to a $\mathrm{pH}$ of 2.8 using a $6 \mathrm{M}$ $\mathrm{HCl}$ stock solution, to which an equal volume $(5 \mathrm{~mL})$ of methyl ethyl ketone was added and the resulting mixture vortexed. Following separation of the organic and aqueous phases, the aqueous phase was collected and dialyzed against 4 $\mathrm{L}$ of water overnight in two $2 \mathrm{~L}$ steps. The resulting protein solution was subsequently dialyzed into $20 \mathrm{mM}$ sodium phosphate, $150 \mathrm{mM}$ sodium chloride, $\mathrm{pH} 7.5$ buffer.

Spectroscopic Measurement of Heme Transfer. Rates of heme transfer from metHb to IsdB ${ }^{\mathrm{N} 1-\mathrm{L}-\mathrm{N} 2}$ and other N1/N2 containing IsdB protein constructs were measured using a 
conventional UV/vis spectrometer (Thermo Evolution 60s) at $25{ }^{\circ} \mathrm{C}$ by monitoring spectral changes of the Soret absorption band at $406 \mathrm{~nm}$ as described in ref 3. Briefly, $4 \mu \mathrm{M}$ holo-metHb (Sigma) was rapidly mixed with $25 \mu \mathrm{M}$ apo-IsdB protein in 20 $\mathrm{mM}$ sodium phosphate, $150 \mathrm{mM}$ sodium chloride, $\mathrm{pH} 7.5$ buffer, and changes in absorbance at $406 \mathrm{~nm}$ were monitored for $30 \mathrm{~min}$. Each reaction was repeated in triplicate. The data was plotted and analyzed using the GraphPad Prism software (GraphPad Software Inc.), and all reactions were fit to a single exponential decay function to extract heme transfer rates and kinetic parameters.

\section{RESULTS}

Three-Dimensional Solution Structure of IsdB ${ }^{\mathrm{N} 1}$. NMR assignments of ${ }^{1} \mathrm{H},{ }^{13} \mathrm{C}$, and ${ }^{15} \mathrm{~N}$ backbone and side-chain atom resonances were accomplished using standard multidimensional $\left({ }^{1} \mathrm{H},{ }^{15} \mathrm{~N},{ }^{13} \mathrm{C}\right)$ experiments as a first step toward solving the $3 \mathrm{D}$ structure of the first NEAT domain of IsdB (IsdB ${ }^{\mathrm{N} 1}$ ) in solution. The resulting chemical shifts have been deposited as BMRB entry $19056 .{ }^{21} \mathrm{~A}$ total of $1535{ }^{1} \mathrm{H}-{ }^{1} \mathrm{H}$ NOEs were identified from analysis of $3 \mathrm{D}{ }^{15} \mathrm{~N}$ - and ${ }^{13} \mathrm{C}$-edited ${ }^{1} \mathrm{H}-{ }^{1} \mathrm{H}$ NOESY spectra. Of these, 825 sequential and long-range NOE together with 277 dihedral angle and 92 hydrogen-bond distance restraints were used for the final $\mathrm{IsdB}^{\mathrm{N} 1}$ structure calculations (Table 1). As mentioned, a structural ensemble of low conformational energy Is $\mathrm{dB}^{\mathrm{N} 1}$ conformers was determined using a standard simulated annealing protocol of CYANA 2.1 followed by "water refinement" of selected conformers using the program AMBER9. An overlay of 20 conformers of IsdB ${ }^{\mathrm{N1}}$ with the lowest residual CYANA target function value, and no NOE or dihedral angle violations greater than $0.5 \AA$ or $5^{\circ}$, respectively, is shown in Figure 1. The ensemble of $\mathrm{IsdB}^{\mathrm{N} 1}$ structures demonstrates that $\mathrm{IsdB}^{\mathrm{N} 1}$ adopts a well-ordered structure spanning residues 124-264, with root-mean-square deviation (RMSD) for the final set of $\mathrm{IsdB}^{\mathrm{N} 1}$ structures relative to a calculated mean structure of $0.65 \AA$ for backbone atoms of residues 129-134, 147-150, 153-157, 174-178, 183-189, 196-202, 205-207, 210-215, 219-227, 233-242, and 245256 , corresponding to IsdB ${ }^{\mathrm{N} 1}$ well-defined secondary structural elements $\alpha 1, \beta 1 \mathrm{a}, \beta 1 \mathrm{~b}, \beta 2, \beta 3, \beta 4, \beta 5 \mathrm{a}, \beta 5 \mathrm{~b}, \beta 6, \beta 7$, and $\beta 8$, respectively (see Figure 2 ). The $\mathrm{C}$-terminal segment of the protein (residues 265-271) is disordered, as evidenced by the lack of short- and long-range ${ }^{1} \mathrm{H}-{ }^{1} \mathrm{H}$ NOEs and the presence of amide hydrogens undergoing fast ${ }^{1} \mathrm{H} /{ }^{2} \mathrm{H}$ solvent exchange. Largest RMSDs apart from the $\mathrm{N}$ - and $\mathrm{C}$-termini of the protein are observed for backbone atoms located in loop regions of Is $\mathrm{dB}^{\mathrm{N} 1}$, including loop 2 spanning residues $158-172$ and labeled L2 in Figure 2. This loop interconnects $\beta$-strands $\beta 1 \mathrm{~b}$ and $\beta 2$, and is comprised of a stretch of aromatic amino acids (F164-Y165-H166-Y167) whose ${ }^{1} \mathrm{H} /{ }^{15} \mathrm{~N}$ amide NMR resonances were unobservable in the $2 \mathrm{D}{ }^{1} \mathrm{H}-{ }^{15} \mathrm{~N}$ HSQC spectra of ${ }^{15} \mathrm{~N}$ or ${ }^{15} \mathrm{~N} /{ }^{13} \mathrm{C}$ IsdB ${ }^{\mathrm{N} 1}$ samples, thus precluding assignment of sequential or short-range NOEs for this region of the protein.

Overall, the $\mathrm{IsdB}^{\mathrm{N} 1}$ structure adopts a characteristic immunoglobin ( $\mathrm{Ig}) \beta$-sandwich-like-fold that is comprised of two antiparallel five-stranded $\beta$-sheets similar but not identical to the architecture of other NEAT domains ${ }^{10-14}$ (see Figure 2). The first five-stranded $\beta$-sheet of $\operatorname{IsdB}^{\mathrm{N} 1}$ is comprised of $\beta$ strands $\beta 1 \mathrm{a}-\beta 2-\beta 3-\beta 6-\beta 5 \mathrm{~b}$, and the second $\beta$-sheet incorporates $\beta$-strands $\beta 1 \mathrm{~b}-\beta 4-\beta 7-\beta 8-\beta 5 \mathrm{a}$. IsdB ${ }^{\mathrm{N} 1}$ 's Ig fold differs from a prototypical $\mathrm{Ig}$ structural motif in that each $\beta$-sheet is comprised of five extended antiparallel $\beta$-strands as compared
Table 1. Structural Statistics for Calculation of $\mathrm{IsdB}^{\mathrm{N} 1} 3 \mathrm{D}$ Structure by NMR

constraints for final structure calculations
total NOE distance restraints
intraresidue
sequential $(|i-j|=1)$

dihedral angle restraints ${ }^{a}$

$\varphi$ angles

136

$\psi$ angles

141

hydrogen bonds restraints ${ }^{b}$

46

structure statistics (20 conformers)

CYANA target function $\left(\AA^{2}\right)^{c}$

residual distance violations number $>0.5 \AA$

Ramachandran plot statistics $(\%)^{d}$ residues in most favored regions 84.6 residues in additionally allowed regions $\quad 13.6$ residues in generously allowed regions residues in disallowed regions

average RMSD to mean structure $(\AA)^{e}$ protein backbone

$0.65 \pm 0.11$ protein heavy atoms

Global Raw Scores $f$

$\begin{array}{lr}\text { Verify3D } & 0.35 \\ \text { Prosall } & 0.51 \\ \text { Procheck }(\varphi-\psi) & -0.69\end{array}$

${ }^{a} \varphi$ and $\psi$ angles were derived from the program TALOS + , based on the ${ }^{13} \mathrm{C}^{\alpha},{ }^{13} \mathrm{C}^{\beta},{ }^{1} \mathrm{H}^{\alpha}$, and ${ }^{15} \mathrm{~N}$ chemical shifts. ${ }^{b_{1}}$ Two distance restraints between the amide and carbonyl group atoms $(\mathrm{NH}-\mathrm{O}=1.8-2.8 \AA$, $\mathrm{N}-\mathrm{O}=2.5-3.8 \AA$ ) were used for the hydrogen bond restraints. ${ }^{c}$ CYANA target function calculated after water refinement in AMBER with the NOE restraints. ${ }^{d}$ Ramachandran plot analysis performed with PROCHECK. ${ }^{e}$ Residues 129-133, 151-156, 175-178, 184-189, 198-202, 209-215, 221-227, 233-242, and 251-256 were used.

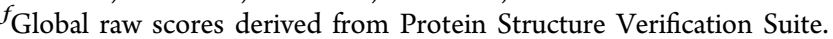

to four in the canonical Ig structural fold. In addition, a short $\alpha$ helical structural element spanning residues 129-134 followed by a long loop (L1) spanning residues 135-146 initiates the $3 \mathrm{D}$ fold of IsdB ${ }^{\mathrm{N} 1}$. This structural feature is not typically seen in other heme-binding NEAT domains but seems characteristic of hemoglobin binding NEAT domains. 9 ,15,17,40

As anticipated, since $\mathrm{IsdB}^{\mathrm{N} 1}$ is closely related to the hemoglobin $(\mathrm{Hb}) /$ haptoglobin $(\mathrm{Hp})$ IsdH receptor, structural alignment of IsdB ${ }^{\mathrm{N} 1}$ using the DALI software ${ }^{37}$ identified two closely related structural homologues, Is $\mathrm{dH}^{\mathrm{N} 1}$ and $\mathrm{IsdH}^{\mathrm{N} 2}$, two of the three NEAT domains of IsdH that participate in $\mathrm{Hb}$ - but not in heme-binding ${ }^{9,17,40}$ (IsdH $^{\mathrm{N} 1}$ PDB entry $2 \mathrm{H} 3 \mathrm{~K}, 2.1 \AA$ RMSD over 139 aligned residues with $43 \%$ sequence identity, and $\mathrm{IsdH}^{\mathrm{N} 2} \mathrm{PDB}$ entry 4IJ2, $2.0 \AA$ RMSD over 133 aligned residues with $65 \%$ identity, respectively).

A structural overlay and sequence alignment of the NEAT motif of $\mathrm{IsdB}^{\mathrm{N} 1}$ with $\mathrm{IsdH} \mathrm{H}^{\mathrm{N} 1}$, IsdH $\mathrm{I}^{\mathrm{N} 2}$, and IsdA is shown in Figure $3 \mathrm{~A}$ and $\mathrm{B}$, respectively. Comparison of $\mathrm{IsdB}^{\mathrm{N} 1}$ with $\mathrm{Is} \mathrm{dH}^{\mathrm{N} 1}$ reveals that the structures are quite similar for core 


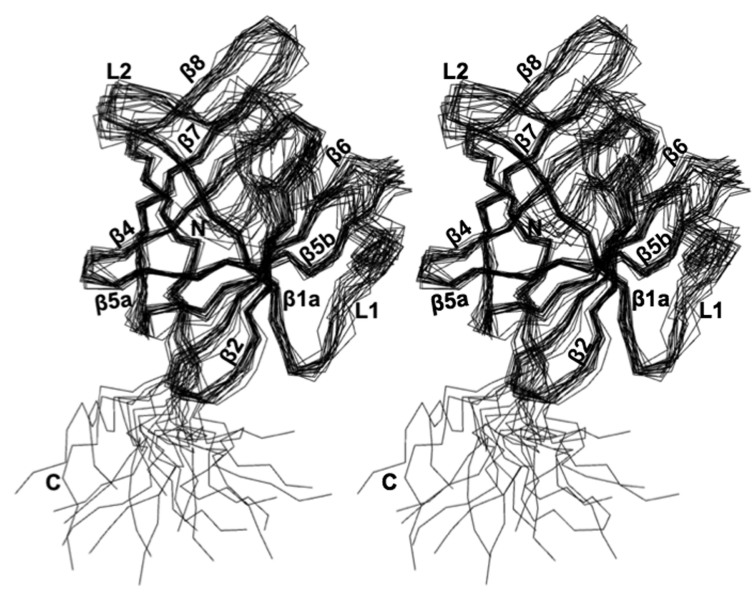

Figure 1. Family of 20 accepted $\mathrm{IsdB}^{\mathrm{N} 1}$ solution NMR structures. The wall-eyed stereoview is shown for the overlay of the backbone heavy atoms $\left(\mathrm{N}, \mathrm{C}_{\alpha}\right.$ and $\left.\mathrm{C}^{\prime}\right)$ of residues 125-272 for the 20 lowest-energy structures. Secondary structure elements and $\mathrm{N}$ - and $\mathrm{C}$-termini are labeled.

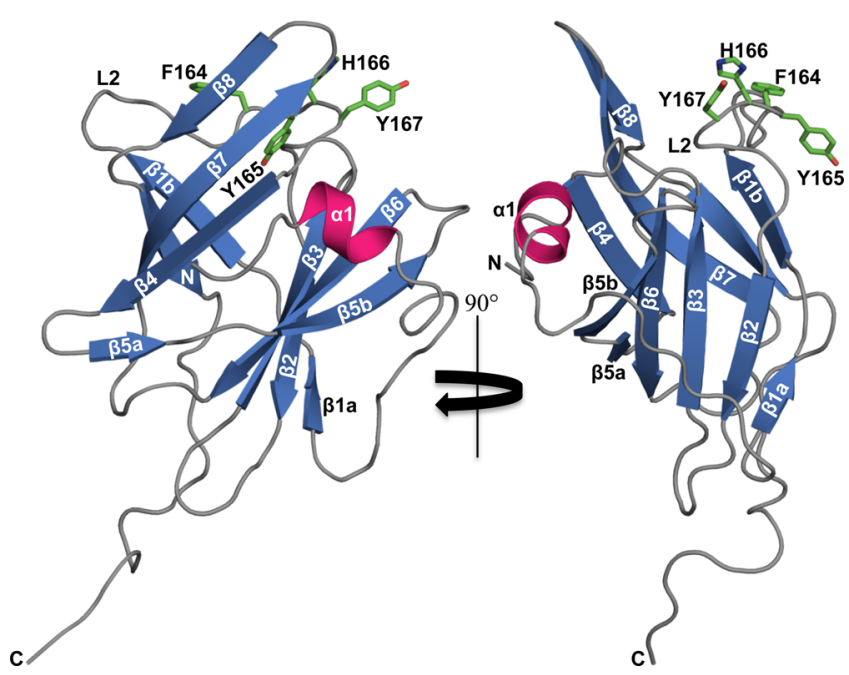

Figure 2. Ribbon representation of a representative conformer from the ensemble of 20 low-energy NMR structures of $\mathrm{IsdB}^{\mathrm{N1}}$. The secondary structure elements are labeled $\alpha 1$ ( $\alpha$-helix 1, residues 129134), $\beta 1 \mathrm{~A}$ ( $\beta$-sheet $1 \mathrm{~A}$, residues $148-150), \beta 1 \mathrm{~B}(\beta$-sheet $1 \mathrm{~B}$, residues $153-157), \beta 2$ ( $\beta$-sheet 2 , residues $173-177), \beta 3(\beta$-sheet 3 , residues $184-190), \beta 4$ ( $\beta$-sheet 4 , residues 196-202), $\beta 5 \mathrm{~A}(\beta$-sheet $5 \mathrm{~A}$, residues $205-207), \beta 5 \mathrm{~B}(\beta$-sheet $5 \mathrm{~B}$, residues $210-215), \beta 6(\beta$-sheet 6 , residues $219-226), \beta 7$ ( $\beta$-sheet 7 , residues $233-242)$, and $\beta 8$ ( $\beta$ sheet 8 , residues $245-249,252-256)$. Side chains of aromatic amino acid residues F164, Y165, H166, and Y167 that comprise the aromatic motif of loop 2 (L2) are shown as stick models.

residues with both comprised of a disordered L2 loop when uncomplexed with metHb. 9 For IsdH ${ }^{\mathrm{N} 1}$ and $\mathrm{IsdH}^{\mathrm{N} 2}$, this disordered loop becomes ordered and forms a short $\alpha$-helix upon binding to metHb, as observed in the crystal structures of these two NEAT domains of IsdH in complex with metHb. ${ }^{9,17,40}$ In contrast, NEAT domains that bind heme such as Isd $\mathrm{A}^{\mathrm{N}}$ have a comparable solvent exposed region, but the latter is devoid of a stretch of aromatic amino acids and adopts a well-folded $\alpha$-helical structure in the absence of heme bound ligand. ${ }^{10}$ Such a structural arrangement appears to be critical to form a well-defined heme-binding pocket of the IsdA $^{\mathrm{N}}$ protein. ${ }^{10}$ The $\mathrm{L} 2$ region (or equivalent) of $S$. aureus
NEAT domains thus appears to be highly adaptable to the specific functions imparted onto NEAT domain structural folds.

Another notable difference between $\mathrm{Hb}$-binding NEAT domains such as $\mathrm{IsdB}^{\mathrm{N} 1}$ and NEAT domains specialized to bind heme is the presence of a short $\mathrm{N}$-terminal $\alpha$-helix followed by an extended loop (L1) which together wrap around the first five-stranded antiparallel $\beta$-sheet of $\mathrm{IsdB}^{\mathrm{N} 1}$ 's Ig-like fold. While this region seems specific to Hb-binding NEAT domains, it is unclear if residues within L1 directly interact with $\mathrm{Hb}$, at least based on examination of reported crystal structures of IsdH $\mathrm{N}^{\mathrm{N} 1} / \mathrm{IsdH}^{\mathrm{N} 2}$-metHb complexes. ${ }^{17,40}$ Our structural study of $\mathrm{Is}_{\mathrm{dB}} \mathrm{N}^{\mathrm{N}}$, however, indicates that this $\mathrm{L} 1$ region is important for the overall global fold and structural stability of $\mathrm{IsdB}^{\mathrm{N} 1}$, as initial investigations of an $\mathrm{IsdB}^{\mathrm{N} 1}$ protein construct spanning only residues 140-270 revealed that the latter was poorly soluble and expressed in insoluble inclusion bodies of $E$. coli (data not shown). The 3D structure of $\mathrm{IsdB}^{\mathrm{N} 1}$ reveals the presence of three hydrophobic amino acids (Leu129, Ile133, and Ile138) that participate in important van der Waals contacts with amino acid residues located in the first fivestranded $\beta$-sheet of $\mathrm{IsdB}^{\mathrm{N} 1}$, and are thus most likely responsible for the decreased stability of our initial IsdB $^{\mathrm{N1}}$ (residues 140270) construct.

Structural Docking of IsdB ${ }^{\mathrm{N} 1}$ onto IsdH $\mathrm{H}^{\mathrm{N} 2}-\mathrm{Hb}$ Complex and Engineering of IsdB ${ }^{\mathrm{N} 1}$ Protein Variants with Altered Hb-Binding Properties. The SSM module of the Coot $\operatorname{program}^{38}$ was utilized to generate a model of $\mathrm{IsdB}^{\mathrm{N} 1}$ in complex with methemoglobin (metHb) (Figure 4). The superposition and docking were based on the recently published crystal structure of an $\mathrm{IsdH}^{\mathrm{N} 2}-\mathrm{Hb}$ complex. ${ }^{40}$ Most notable in the model is that the disordered L2 loop region of $\mathrm{IsdB}^{\mathrm{N} 1}$ is positioned opposite of the two $\alpha$-helices $\mathrm{A}$ and $\mathrm{E}$ of the $\alpha$-subunit of metHb (Figure 4). In the solution structure of Is $\mathrm{dH}^{\mathrm{N} 1}$, a comparable loop (Loop 2) to that of $\mathrm{IsdB}^{\mathrm{N} 1}$, comprised of $\mathrm{IsdH}^{\mathrm{N} 1}$ residues Y125-Y126-H127-F128-F129$\mathrm{S} 130$, is disordered in the free form of $\mathrm{IsdH}^{\mathrm{N} 1},{ }^{9}$ but undergoes a conformational change to form a short $\alpha$-helix upon $\mathrm{Hb}$ binding as observed in the crystal structure of $\mathrm{IsdH}^{\mathrm{N} 1}: \mathrm{Hb}^{17}$ Equivalent amino acid residues of $\mathrm{IsdH}^{\mathrm{N} 2}$ undergo a similar transition upon $\mathrm{Hb}$ binding to form a well-ordered short $\alpha$-helix upon formation of an $\mathrm{IsdH}^{\mathrm{N} 2}: \mathrm{Hb}$ complex. ${ }^{40}$ Two aromatic residues in the loop 2 structure of $\mathrm{IsdH}^{\mathrm{N} 2}$ in particular, F365 and $\mathrm{Y} 368$, appear to be key modulators of $\mathrm{IsdH}^{\mathrm{N} 2}$ binding to metHb, as their side chains project outward from IsdH ${ }^{\mathrm{N2}}$,s short $\alpha$-helix structure and position themselves at the interface of the Isd $\mathrm{H}^{\mathrm{N} 2}$ :metHb complex. ${ }^{40}$

Considering the high sequence conservation between $\mathrm{IsdB}^{\mathrm{N} 1}$ and $\mathrm{IsdH}^{\mathrm{N} 2}$, examination of our model of $\mathrm{IsdB}^{\mathrm{N} 1}:$ metHb protein suggests that aromatic residues F164 and Y167 of $\mathrm{IsdB}^{\mathrm{N} 1}$ may be key elements of Is $\mathrm{dB}^{\mathrm{N} 1}$, s $\mathrm{Hb}$-binding interface and may participate in critical interactions with metHb. To investigate this possibility, three additional $\mathrm{IsdB}^{\mathrm{N} 1}$ protein constructs (i.e., IsdB ${ }^{\mathrm{N} 1} \mathrm{~F} 164 \mathrm{D}$ and $\mathrm{Y} 167 \mathrm{D}$ single mutants, and F164D/Y167D double mutant) were engineered, with F164 and Y167 replaced by aspartic acid. Aspartic acid was selected as amino acid choice for the site-directed mutagenesis experiments because we anticipate that Asp, as a negatively charged residue, would have a greater disrupting effect on $\mathrm{IsdB}^{\mathrm{N} 1}$ 's capability to bind metHb. Investigations of IsdB ${ }^{\mathrm{N} 1}$ proteins containing F164D, Y167D, and F164D/Y167D amino acid substitutions could thus provide strong evidence that the $\mathrm{Hb}$-binding site of $\mathrm{IsdB}^{\mathrm{N} 1}$ includes these aromatic residues within loop 2, and that hydrophobic interactions mediated by 
(A)
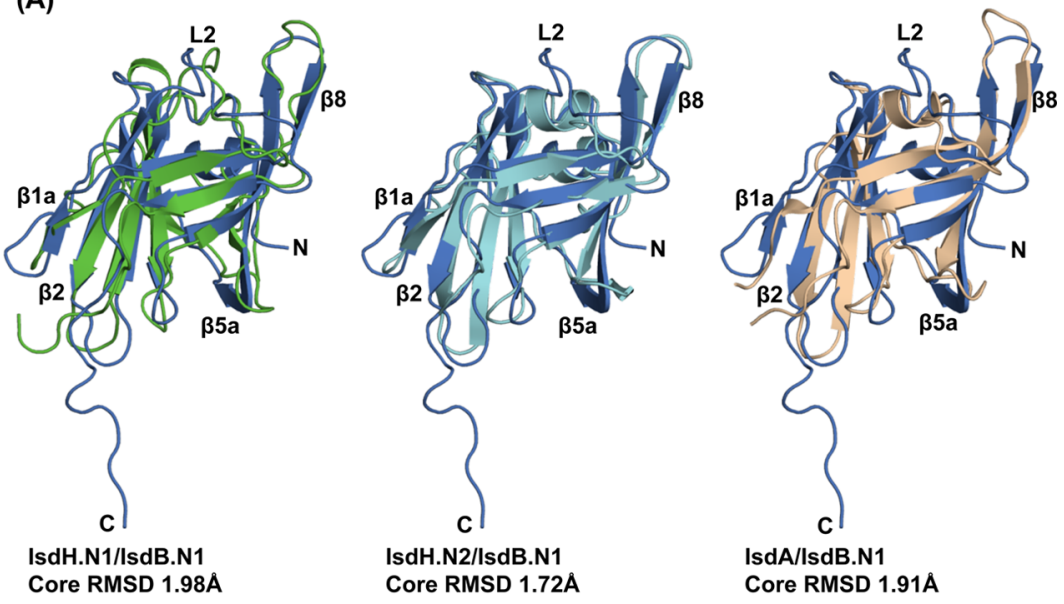

(B)

IsdB.N1
IsdH.N2
IsdH.N1
IsdA

IsdB.N1
IsdH.N2
IsdH.N1
IsdA

IsdB.N1
IsdH.N2
IsdH.N1
IsdA.

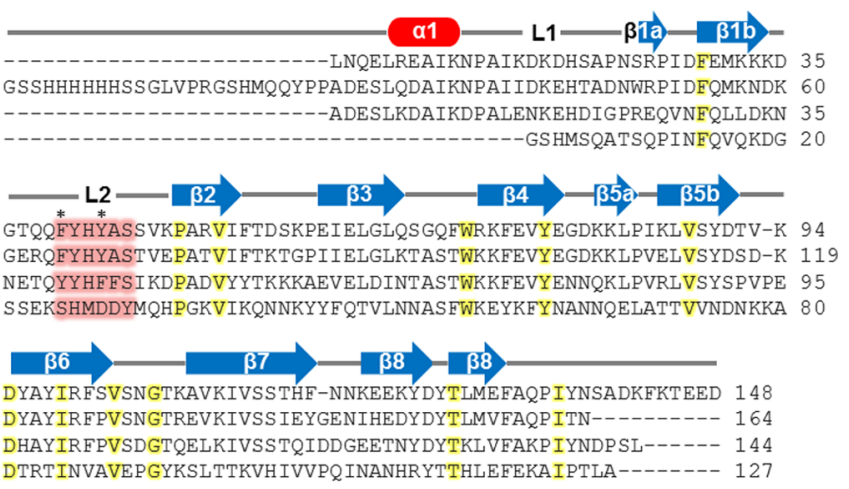

Figure 3. (A) Comparison of the $3 \mathrm{D}$ structure of $\mathrm{IsdB}^{\mathrm{N1}}$ (blue) with that of other NEAT domain containing proteins: IsdH ${ }^{\mathrm{N} 1}$ (green, PDB entry $2 \mathrm{H} 3 \mathrm{~K}$ ), IsdH ${ }^{\mathrm{N} 2}$ (cyan, PDB entry $4 \mathrm{FC} 3$ ), and IsdA ${ }^{\mathrm{N}}$ (light brown, PDB entry 3QZN) with secondary structural elements and L2 labeled. (B) ClustalW primary sequence alignment of $\mathrm{IsdB}^{\mathrm{N} 1}$ with $\mathrm{IsdH}^{\mathrm{N} 1}$, IsdH $\mathrm{H}^{\mathrm{N} 2}$, and IsdA, with strictly conserved amino acid residues highlighted in yellow, aromatic residues within $\mathrm{L} 2$ in red, and aromatic amino acids that were substituted by aspartic acids within IsdB ${ }^{\mathrm{N} 1}$ sequence denoted by an asterisk (*) above their one-letter code. The location of $\mathrm{IsdB}^{\mathrm{N} 1}$ secondary structural elements is shown above the sequence.

$\mathrm{F} 164$ and $\mathrm{Y} 167$ in wild type $\mathrm{IsdB}^{\mathrm{N} 1}$ are crucial for the formation of an $\mathrm{IsdB}^{\mathrm{N} 1}$ :metHb complex capable of transferring heme from metHb to IsdB.

Monitoring of $\mathrm{IsdB}^{\mathrm{N} 1}$ Binding to metHb by Size Exclusion Chromatography and 2D ${ }^{1} \mathrm{H}-{ }^{15} \mathrm{~N}$ Correlation HSQC NMR Spectroscopy. We examined $\mathrm{IsdB}^{\mathrm{N} 1}$ 's ability to bind metHb using size exclusion chromatography (SEC). When injected singly, IsdB ${ }^{\mathrm{N} 1}$ and metHb migrate as single species with apparent molecular mass of $19.4 \mathrm{kDa}$ and 32.5 $\mathrm{kDa}$, consistent with monomeric and dimeric forms, respectively. At a $6: 1$ molar ratio $\mathrm{IsdB}^{\mathrm{N} 1}:$ metHb, the migration time (of metHb) is identical to the elution time of metHb alone (Figure 5, chromatograms 1 and 2), indicating that formation of a tight complex between $\mathrm{IsdB}^{\mathrm{N} 1}$ and metHb does not occur. In contrast, mixtures of metHb with IsdH ${ }^{\mathrm{N} 1}$ and $\mathrm{IsdH}^{\mathrm{N} 2}$ at a 6:1 molar ratio under identical conditions shifted the metHb peak to now elute earlier (Figure 5, chromatogram 3 and 4). The change in elution volume correlated to an increase in molecular mass of $\sim 19 \mathrm{kDa}$, consistent with both $\mathrm{IsdH}^{\mathrm{N} 1}$ and $\mathrm{IsdH}^{\mathrm{N} 2}$ preferentially binding one subunit of the $\alpha / \beta$ metHb dimer, at least under the experimental SEC conditions. Thus, despite both high sequence and structural similarities to $\mathrm{IsdH}^{\mathrm{N} 1}$ and Is $\mathrm{dH}^{\mathrm{N} 2}$, IsdB $\mathrm{B}^{\mathrm{N} 1}$ has subtle yet significant differences in its interactions with metHb.

To establish whether $\mathrm{IsdB}^{\mathrm{N} 1}$ does bind metHb, but just with a much lower affinity than that detectable by gel filtration,
NMR titration experiments were used to investigate the metHb binding reaction to $\mathrm{IsdB}^{\mathrm{N} 1}$. NMR conditions allow for the "ligand" and "receptor" concentrations to be kept much higher, thus permitting the probing of weaker affinity interactions observed via observation of changes in amide ${ }^{1} \mathrm{H} /{ }^{15} \mathrm{~N}$ chemical shifts, NMR signal intensity, and/or increases in spectral line broadening as a function of the progressive addition of one reactant to the other. Selective $2 \mathrm{D}{ }^{1} \mathrm{H}-{ }^{15} \mathrm{~N}$ correlation HSQC spectra from these titration experiments are shown in Figure 6. In the absence of metHb free in solution, the $2 \mathrm{D}{ }^{1} \mathrm{H}-{ }^{15} \mathrm{~N}$ HSQC spectrum of IsdB ${ }^{\mathrm{N} 1}$ exhibits well-resolved $\mathrm{NH}$ signals with ${ }^{1} \mathrm{H}$ and ${ }^{15} \mathrm{~N}$ resonance linewidths characteristic of a wellfolded monomeric $18 \mathrm{kDa}$ protein (Figure 6, panel A). Progressive titration of ${ }^{15} \mathrm{~N}-\mathrm{IsdB}^{\mathrm{N} 1}$ up to a $1: 1$ molar ratio of metHb to IsdB ${ }^{\mathrm{N} 1}$ elicited significant spectral changes in the $2 \mathrm{D}$ ${ }^{1} \mathrm{H}-{ }^{15} \mathrm{~N}$ HSQC spectrum of ${ }^{15} \mathrm{~N}-\mathrm{IsdB}^{\mathrm{N}}$. Most notable were the significant loss of spectral intensity for the majority of the $\mathrm{NH}$ resonances and significant spectral line broadening (Figure 6, panel B). Upon further addition of ${ }^{15} \mathrm{~N}-\mathrm{IsdB}^{\mathrm{N} 1}$ to this solution mixture and up to a $3: 1 \mathrm{IsdB}^{\mathrm{N} 1}$ :metHb molar ratio, well dispersed ${ }^{15} \mathrm{~N} /{ }^{1} \mathrm{H}$ amide resonances were again observable and signal intensity recovered (Figure 6, panel C), indicating that addition of excess ${ }^{15} \mathrm{~N}$-IsdB ${ }^{\mathrm{N} 1}$ does not result in formation of a larger nonspecific aggregate with metHb but rather that the excess ${ }^{15} \mathrm{~N}-\mathrm{IsdB}^{\mathrm{N} 1}$ protein remains free in solution. Specificity of the IsdB ${ }^{\mathrm{N} 1}$ :metHb binding reaction was further verified by 


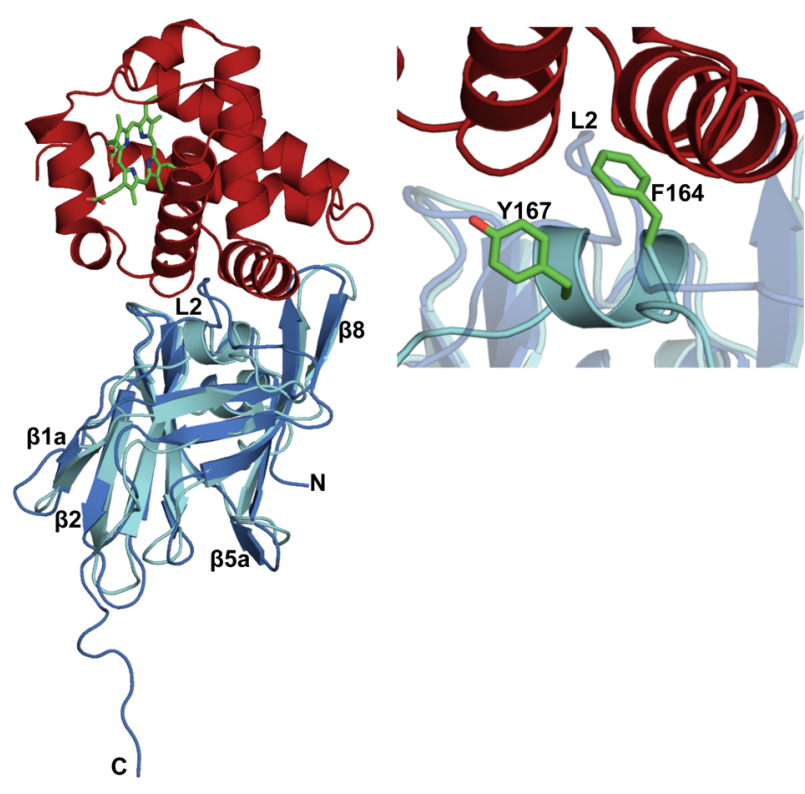

Figure 4. Ribbon representation of $\mathrm{IsdB}^{\mathrm{N} 1}$ (blue) superimposed onto the crystal structure of the $\mathrm{IsdH}^{\mathrm{N} 2}$ (cyan) in complex with hemoglobin (red) (PDB entry 4FC3), depicting interactions of $\mathrm{IsdB}^{\mathrm{N} 1} \mathrm{~L} 2$ with metHb. IsdB ${ }^{\mathrm{N} 1}$ docking model was generated using the SSM module of the Coot software. On the right-hand side, a zoomed in inset of Is $\mathrm{BB}^{\mathrm{N} 1} \mathrm{~L} 2$ residues possibly interacting with metHb and stick model representations of Y167 and F164 side chains that were mutated to Asp as discussed in the text.

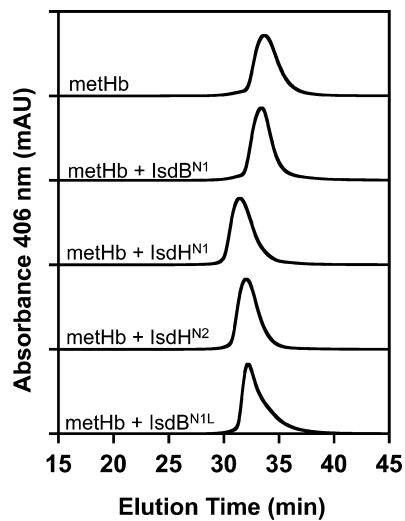

Figure 5. Size-exclusion chromatography of metHb and Isd proteins. Gel filtration chromatogram of free metHb (top), 1:6 metHb:IsdB ${ }^{\mathrm{N} 1}$ complex, 1:6 metHb:IsdH ${ }^{\mathrm{N} 1}$ complex, 1:6 metHb:IsdH ${ }^{\mathrm{N} 2}$ complex, and 1:6 metHb:IsdB ${ }^{\mathrm{N1}-\mathrm{L}}$ complex (bottom). Each plot depicts the absorbance of the heme Soret band at $406 \mathrm{~nm}$. Stacked chromatograms are displayed with an offset of 200 milli-absorbance units. The dashed line indicates the elution time of free metHb. The decrease in elution volume for $\mathrm{IsdH}^{\mathrm{N} 1}$ and $\mathrm{IsdH}^{\mathrm{N} 2}$ in complex with metHb correlates to an increase in molecular mass of $19 \mathrm{kDa}$ consistent with one IsdH Neat domain binding metHb. The decrease in elution volume of $\mathrm{IsdB}^{\mathrm{N1} 1 \mathrm{~L}}$ in complex with metHb correlates to an increase in molecular mass of $\sim 10 \mathrm{kDa}$, indicating less than one $\mathrm{IsdB}^{\mathrm{N1}-\mathrm{L}}$ bound per metHb.

adding unlabeled $\mathrm{IsdB}^{\mathrm{N} 1}$ to an NMR sample mixture of the $1: 1$ ${ }^{15} \mathrm{~N}-\mathrm{IsdB}^{\mathrm{N} 1}$ :metHb complex. Addition of unlabeled $\mathrm{IsdB}^{\mathrm{N} 1}$ to the solution mixture causes ${ }^{15} \mathrm{~N} /{ }^{1} \mathrm{H}$ amide signals of free ${ }^{15} \mathrm{~N}$ Is $\mathrm{dB}^{\mathrm{N} 1}$ to reappear in the corresponding $2 \mathrm{D}{ }^{1} \mathrm{H}-{ }^{15} \mathrm{~N}$ correlation HSQC spectrum (Figure 6, panel D). These data indicate that unlabeled $\mathrm{IsdB}^{\mathrm{N} 1}$ is able to compete out the ${ }^{15} \mathrm{~N}$ -
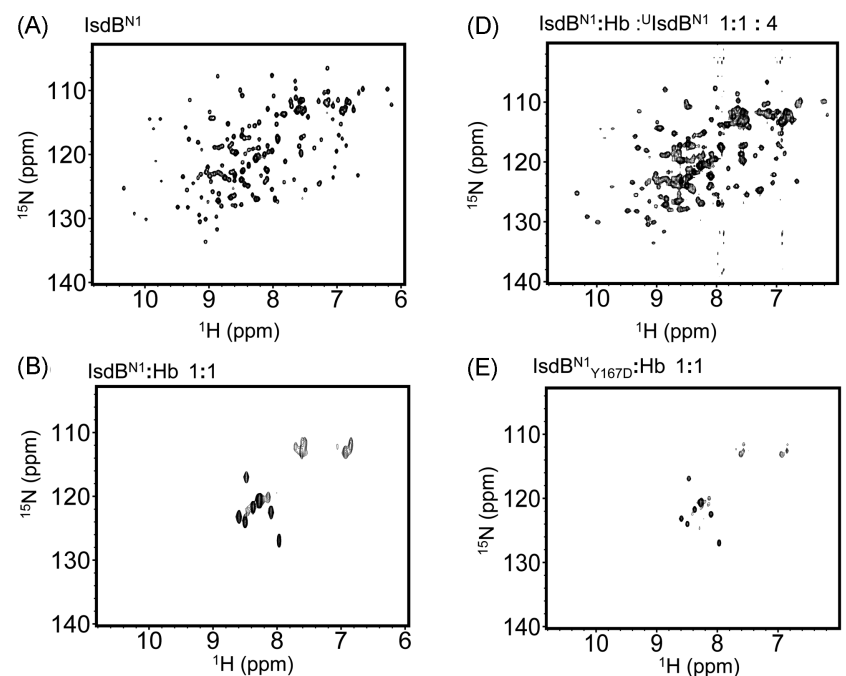

(E) $\quad$ IsdB $^{\mathrm{N} 1}{ }_{Y 167 \mathrm{D}}: \mathrm{Hb} 1: 1$
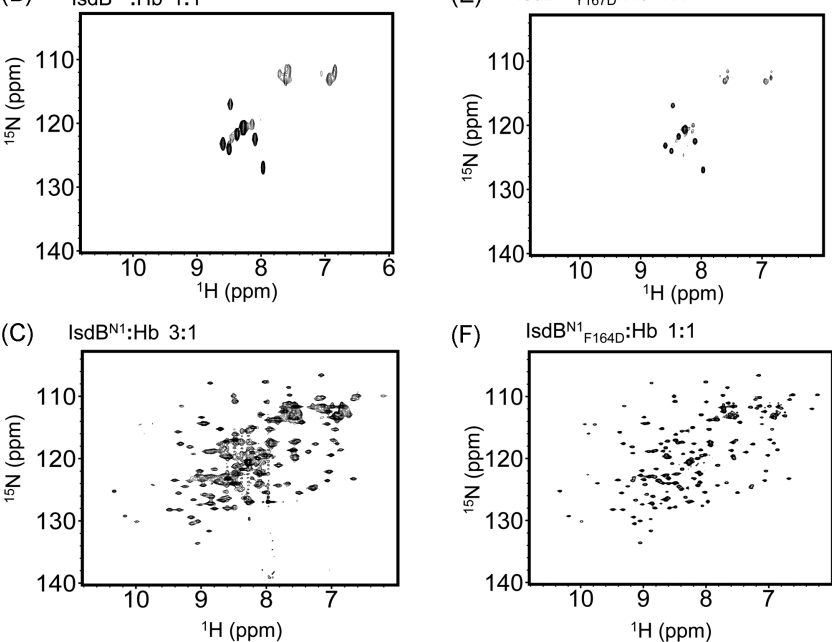

(F) $\quad \mathrm{IsdB}^{\mathrm{N} 1}{ }_{\mathrm{F} 164 \mathrm{D}}: \mathrm{Hb} \quad 1: 1$

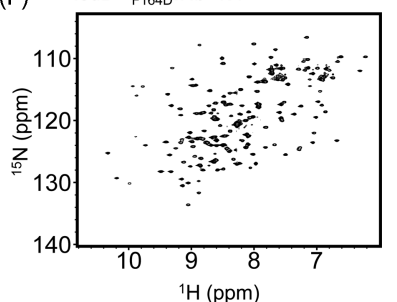

Figure 6. NMR titration study of metHb binding to $\mathrm{IsdB}^{\mathrm{N} 1}$. The panels present resulting $2 \mathrm{D}{ }^{1} \mathrm{H}-{ }^{15} \mathrm{~N}$ HSQC spectra following addition of varying amounts of $\mathrm{IsdB}^{\mathrm{N} 1}$ or $\mathrm{IsdB}^{\mathrm{N1}}$ protein variants to a fixed amount of $\mathrm{Hb}$. (A) Free ${ }^{15} \mathrm{~N}-\mathrm{IsdB}^{\mathrm{N} 1}$, (B) $1: 1{ }^{15} \mathrm{~N}-\mathrm{IsdB}^{\mathrm{N} 1}: \mathrm{Hb}$ complex, (C) $3: 1{ }^{15} \mathrm{~N}-\mathrm{IsdB}^{\mathrm{N1}}: \mathrm{Hb}$ complex, (D) $1: 1^{15} \mathrm{~N}-\mathrm{IsdB}^{\mathrm{N} 1}: \mathrm{Hb}$ with $4 \times$ equivalent of unlabeled-IsdB ${ }^{\mathrm{N1}}$ added, (E) $1: 1{ }^{15} \mathrm{~N}-\mathrm{IsdB}^{\mathrm{N} 1(\mathrm{Y} 167 \mathrm{D})}: \mathrm{Hb}$, and (F) $1: 1{ }^{15} \mathrm{~N}-\mathrm{IsdB}^{\mathrm{N1}(\mathrm{F} 164 \mathrm{D})}: \mathrm{Hb}$. The ratios of protein concentrations are shown above each panel. The metHb ratios are expressed in terms of a dimeric $\alpha \beta$ (MW $32.5 \mathrm{kDa}$ ) metHb species.

labeled IsdB ${ }^{\mathrm{N} 1}$ which is originally bound to metHb, and that formation of a specific Is $\mathrm{dB}^{\mathrm{N} 1}$ :metHb complex is reversible.

Additionally, to further rule out that these spectral changes are not due to nonspecific protein aggregation but rather are caused by specific binding of $\mathrm{IsdB}^{\mathrm{N} 1}$ to metHb, these titration experiments were repeated using apoHb (lacking heme) and an unrelated ${ }^{15} \mathrm{~N}$-labeled crenarchaeal viral protein, E73, whose structure has been solved in our laboratory and which does not interact with metHb. ${ }^{41}$ As shown in Supporting Information Figure $\mathrm{S} 1$, titration of apoHb up to $1: 1$ molar ratio with $\mathrm{IsdB}^{\mathrm{N} 1}$ had no effect on the corresponding $2 \mathrm{D}-{ }^{1} \mathrm{H}-{ }^{15} \mathrm{~N}$ HSQC spectrum of ${ }^{15} \mathrm{~N}-\mathrm{IsdB}^{\mathrm{N}}$. Similarly, no increase in $\mathrm{NH}$ resonance linewidths or loss of signal intensity was observed upon addition of metHb to an unrelated ${ }^{15} \mathrm{~N}$-E73 protein NMR sample (data not shown). These data thus confirm that complex formation between ${ }^{15} \mathrm{~N}-\mathrm{IsdB}^{\mathrm{N} 1}$ and metHb is the results of specific interactions between the two proteins, and that the loss of signal intensity observed in corresponding 2D ${ }^{1} \mathrm{H}-{ }^{15} \mathrm{~N}$ correlation HSQC spectra of ${ }^{15} \mathrm{~N}-\mathrm{IsdB}^{\mathrm{N} 1}$ :metHb samples is due to the slower overall reorientation time of the complex in solution compared to free ${ }^{15} \mathrm{~N}-\mathrm{IsdB}^{\mathrm{N} 1}$.

Analogous 2D ${ }^{1} \mathrm{H}-{ }^{15} \mathrm{~N}$ correlation NMR titration experiments were conducted using the $\mathrm{IsdB}^{\mathrm{N} 1}$ protein variants described above to assess the effect of amino acid substitutions of $\mathrm{L} 2$ residues on the metHb binding properties of $\mathrm{IsdB}^{\mathrm{N} 1}$. Similar to what is observed for wild-type $\mathrm{IsdB}^{\mathrm{N} 1}$, titration of 
${ }^{15} \mathrm{~N}-\mathrm{IsdB}^{\mathrm{N} 1(\mathrm{Y} 167 \mathrm{D})}$ up to a $1: 1$ molar ratio of ${ }^{15} \mathrm{~N}$ Is $\mathrm{dB}^{\mathrm{N1}(\mathrm{Y} 167 \mathrm{D})}$ :metHb resulted in the same near complete disappearance of $\mathrm{NH}$-resonance signals in the corresponding 2D ${ }^{1} \mathrm{H}-{ }^{15} \mathrm{~N}$ HSQC spectrum of the complex (Figure 6, panels $\mathrm{E}$ and $\mathrm{B}$ ), indicating that, from an NMR standpoint, IsdB $^{\mathrm{N1}(\mathrm{Y} 167 \mathrm{D})}$ can still form a complex with metHb. Further addition of ${ }^{15} \mathrm{~N}-\mathrm{IsdB}^{\mathrm{N} 1(\mathrm{Y} 167 \mathrm{D})}$ to the solution mixture resulted in the full reappearance of ${ }^{1} \mathrm{H} /{ }^{15} \mathrm{~N}$ amide signals in resulting $2 \mathrm{D}$ ${ }^{1} \mathrm{H}-{ }^{15} \mathrm{~N}$ HSQC spectra, although at a noticeable lower excess concentration than what was needed for the wild-type ${ }^{15} \mathrm{~N}$ Is $\mathrm{dB}^{\mathrm{N} 1}$ titration experiments. Addition of unlabeled IsdB $^{\mathrm{N1}(\mathrm{Y} 167 \mathrm{D})}$ to the $1: 1{ }^{15} \mathrm{~N}-\mathrm{IsdB}^{\mathrm{N1}(\mathrm{Y} 167 \mathrm{D})}$ :metHb sample resulted in the recovery of $\mathrm{NH}$ signal intensities, also at a lower concentration than what was needed for wild type $\mathrm{IsdB}^{\mathrm{N} 1}$, suggesting that $\mathrm{IsdB}^{\mathrm{N1}(\mathrm{Y} 167 \mathrm{D})}$ forms a weaker complex with metHb and that $\mathrm{Y} 167$ modulates, albeit weakly, IsdB ${ }^{\mathrm{N} 1}$. metHb protein-protein interactions. In contrast, progressive titration of ${ }^{15} \mathrm{~N}-\mathrm{IsdB}^{\mathrm{N1}(\mathrm{F} 164 \mathrm{D})}$ with metHb resulted in no perturbation of signal intensity, or chemical shift changes, or line broadening of $\mathrm{NH}$ signal in the $2 \mathrm{D}{ }^{1} \mathrm{H}-{ }^{15} \mathrm{~N}$ correlation HSQC spectrum of the ${ }^{15} \mathrm{~N}-\mathrm{IsdB}^{\mathrm{N1}(\mathrm{F} 164 \mathrm{D})}$ : metHb mixture at equal molar ratios (Figure 6, panel E), indicating that substitution of Asp for Phe at residue position 164 completely abrogates $\mathrm{IsdB}^{\mathrm{N1}}$ binding to metHb at least under the conditions of these NMR titration experiments, and that $\mathrm{F} 164$ is a critical mediator of $\mathrm{IsdB}^{\mathrm{N1}}-\mathrm{Hb}$ protein-protein interactions. Taken together, $\mathrm{IsdB}^{\mathrm{N} 1}$ can form a weak complex with metHb and $\mathrm{F} 164$ within the $\mathrm{L} 2$ loop region of $\mathrm{IsdB}^{\mathrm{N} 1}$ is indeed a critical mediator of $\mathrm{IsdB}^{\mathrm{N} 1}:$ metHb protein-protein interactions.

Heme Transfer Experiments. The effects of amino acid substitutions within the $\mathrm{Hb}$-binding region of $\mathrm{IsdB}^{\mathrm{N} 1}$ on the rate of heme transfer from metHb to IsdB ${ }^{\mathrm{N} 1-\mathrm{L}-\mathrm{N} 2}$ were assessed by monitoring changes in UV-visible absorption of the Soret band at $406 \mathrm{~nm}$. Mixing of wild-type IsdB ${ }^{\text {N1-L-N2 }}$ with metHb (Figure 7A) results in a rapid decrease in the absorbance band at $406 \mathrm{~nm}$ which, when plotted as a function of time, could be best fit with a single exponential decay function with an observed rate constant of $k_{\text {lobs }}=0.040 \pm 0.001 \mathrm{~s}^{-1}$. Substituting Y167 to Asp (i.e., mixing of $\operatorname{IsdB}^{\mathrm{N} 1(\mathrm{Y} 167 \mathrm{D})-\mathrm{L}-\mathrm{N} 2}$ with metHb) showed little effect on the rapid heme transfer rate between IsdB and metHb $\left(k_{\text {lobs }}=0.062 \pm 0.001 \mathrm{~s}^{-1}\right)$, suggesting that Y167 does not contribute significantly to IsdB-Hb interactions that promote heme transfer from metHb to the NEAT 2 domain of IsdB. This result is consistent with the NMR titration experiments which indicated that the $2 \mathrm{D}{ }^{1} \mathrm{H}-{ }^{15} \mathrm{~N}$ HSQC spectrum of ${ }^{15} \mathrm{~N}$-labeled $\mathrm{IsdB}^{\mathrm{N1}(\mathrm{Y} 167 \mathrm{D})}$ :metHb complex is very similar to the $2 \mathrm{D}{ }^{1} \mathrm{H}-{ }^{15} \mathrm{~N}$-HSQC spectrum of wild-type ${ }^{15} \mathrm{~N}$ labeled IsdB ${ }^{\mathrm{N} 1}$ :metHb complex (Figure 6, panels E and B). In contrast, the heme transfer rate between metHb and $\mathrm{IsdB}^{\mathrm{N1}(\mathrm{F} 164 \mathrm{D})-\mathrm{L}-\mathrm{N} 2}$ displayed a 4-fold decrease compared to wildtype IsdB ${ }^{\mathrm{N} 1-\mathrm{L}-\mathrm{N} 2}$. Unexpectedly, the F164 mutation did not abolish heme capture despite the apparent absence of metHb binding in the NMR titration experiments. The intermediate rate suggests that although F164 contributes to metHb binding, the substitution to Asp is not sufficient to completely abrogate all metHb binding and subsequent heme transfer from metHB to IsdB (Figure 7A). Interestingly, a re-examination of the docked IsdB ${ }^{\mathrm{N} 1}$-metHb structure shows that the disruptive effects expected for substitution of F164 to Asp may have been offset by formation of a buried salt bridge with Lys 11 of metHb. Indeed substituting F164 to Ala eliminates this
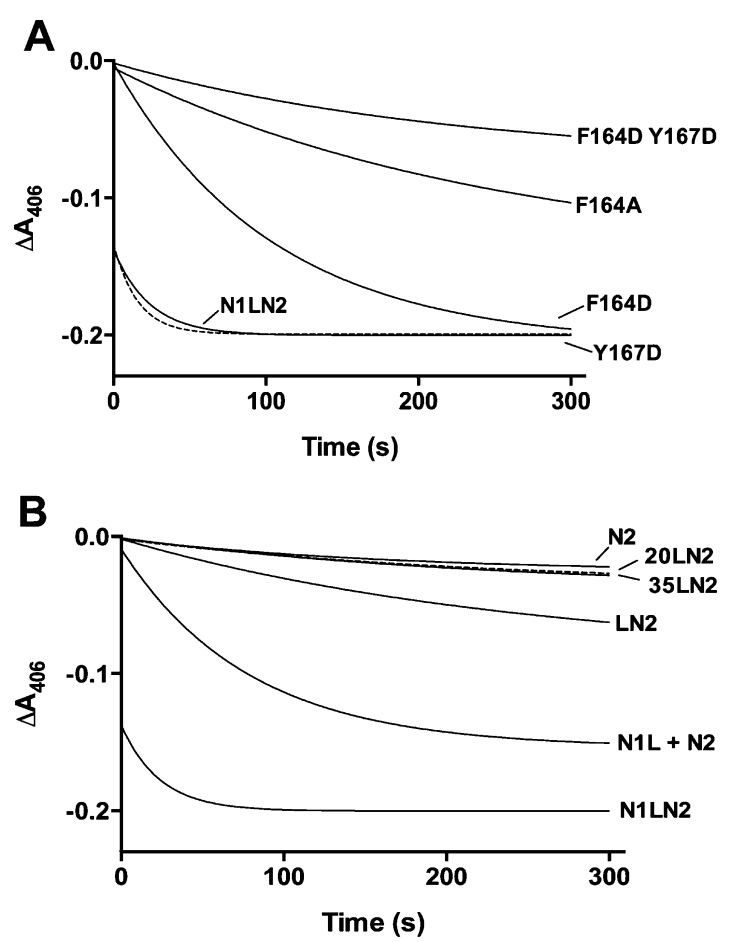

Figure 7. Heme transfer experiments by various IsdB protein fragments. (A) Time courses for the heme transfer reaction of $4 \mu \mathrm{M}$ holo- $\mathrm{Hb}$ to $25 \mu \mathrm{M}$ of $\mathrm{IsdB}^{\mathrm{N} 1-\mathrm{L}-\mathrm{N} 2}$, IsdB single mutant proteins

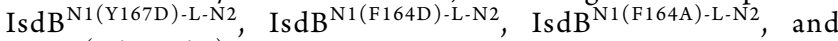

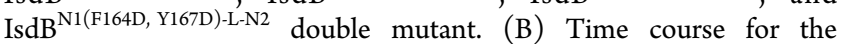
heme transfer reaction of $4 \mu \mathrm{M}$ holo-Hb to $25 \mu \mathrm{M}$ of IsdB ${ }^{\text {N1-L-N2 }}$ $\mathrm{IsdB}{ }^{\mathrm{N} 1-\mathrm{L}}+\mathrm{IsdB}^{\mathrm{N} 2}, \mathrm{IsdB}^{\mathrm{L}-\mathrm{N} 2}, \mathrm{IsdB}^{35 \mathrm{~L}-\mathrm{N} 2}, \mathrm{IsdB}^{20 \mathrm{~L}-\mathrm{N} 2}$, and $\mathrm{IsdB}^{\mathrm{N} 2}$. Heme transfer was followed by monitoring changes in absorbance at $406 \mathrm{~nm}$ over a $30 \mathrm{~min}$ time period. Only the first $5 \mathrm{~min}$ of the reactions are shown for clarity.

interaction, and mixing IsdB $\mathrm{dB}^{\mathrm{N} 1 \text { (F164A)-L-N2 }}$ with metHb results in a slower rate of heme transfer from metHB to IsdB (Figure 7A). Only upon mutations of both F164 and Y167 aromatic residues to Asp (IsdB ${ }^{\mathrm{N} 1(\mathrm{~F} 164 \mathrm{D}, \mathrm{Y} 167 \mathrm{D})-\mathrm{L}-\mathrm{N} 2}$ ) is heme transfer between metHb and IsdB virtually abolished $\left(k_{\text {lobs }}=0.004 \pm\right.$ $0.001 \mathrm{~s}^{-1}$ ) (Figure 7A). The heme transfer rate for this Is $\mathrm{dB}$ double mutant is now equivalent to the rate of heme transfer for IsdB proteins lacking the NEAT 1 domain (i.e., $\mathrm{IsdB}^{\mathrm{L}-\mathrm{N} 2}$ and $\left.k_{1 \mathrm{obs}}=0.004 \pm 0.001 \mathrm{~s}^{-1}\right)$. Interestingly, a small but consistent difference is observed in the heme transfer rates between metHb and IsdB ${ }^{\mathrm{N} 1(\mathrm{~F} 164 \mathrm{D}, \mathrm{Y} 167 \mathrm{D})-\mathrm{L}-\mathrm{N} 2}$ and IsdB ${ }^{\mathrm{L}-\mathrm{N} 2}$ versus that of metHb and $\mathrm{IsdB}^{\mathrm{N} 2}$. Since $\mathrm{IsdB}^{\mathrm{N} 2}$ does not interact with metHb directly, and its slow heme transfer rate is thought to represent spontaneous heme dissociation from metHb and reassociation with the apo-N2 domain, the slightly faster heme transfer rate observed with IsdB ${ }^{\mathrm{L}-\mathrm{N} 2}$ and $\mathrm{IsdB}^{\mathrm{N} 1(\mathrm{~F} 164 \mathrm{D}, \mathrm{Y} 167 \mathrm{D})-\mathrm{L}-\mathrm{N} 2}$ suggests that residues within the linker region contribute to metHb binding. Further analysis of the two constructs Is $\mathrm{dB}^{35 \mathrm{LN} 2}$ and IsdB ${ }^{20 \mathrm{LN} 2}$ (which contain 35 and 20 residues of the linker region extending from the $\mathrm{N} 2$ domain) exhibit comparable heme transfer rates to that of the $\mathrm{IsdB}^{\mathrm{N} 2}$ only domain, indicating that metHb interacting residues may reside within the first half of the linker region. Consistent with these results, size exclusion chromatography of a $6: 1$ molar ratio $\mathrm{IsdB}^{\mathrm{N1} 1-\mathrm{L}}$ :metHb mixture now showed a decrease in the elution time of metHb, indicating IsdB ${ }^{\mathrm{N} 1-\mathrm{L}}$ can form a complex with metHb (Figure 5).

To investigate the effect of linker further, we re-examined the heme transfer ability of $\mathrm{IsdB}^{\mathrm{N} 1-\mathrm{L}}+\mathrm{IsB}^{\mathrm{N} 2}$ under the same 
conditions. As reported, addition of the linker region to the NEAT 1 domain accelerates the heme transfer rate far greater than when attached to the $\mathrm{IsdB}^{\mathrm{N} 2}$ domain. ${ }^{42}$ Since SEC analysis of $\mathrm{IsdB}^{\mathrm{N} 1-\mathrm{L}}$ :metHb did not show any presence of free heme, the increase in the heme transfer rate between metHb and $\mathrm{IsdB}^{\mathrm{N} 2}$ would have to be attributed to an increase in the efficiency of heme extraction by IsdB $\mathrm{N}^{\mathrm{N} 2}$ as a result of covalent attachment to IsdB NEAT1 and linker domains.

Overall, these results demonstrate that amino acid residues within loop 2 of $\mathrm{IsdB}^{\mathrm{N} 1}$ and, in particular, F164 contribute to the $\mathrm{Hb}$ binding site of $\mathrm{IsdB}$, and that efficient heme extraction from $\mathrm{Hb}$ and efficient heme transfer to IsdB require synergistic interactions between all three IsdB N1, linker, and $\mathrm{N} 2$ domains (IsdB $^{\mathrm{N} 1-\mathrm{L}-\mathrm{N} 2}$ ).

IsdB ${ }^{\mathrm{N} 1}$-Linker Interactions. Since increases in heme transfer function and affinity to metHb by $\mathrm{IsdB}^{\mathrm{N} 1}$ following covalent attachment of the linker domain could have arisen from a structural change in $\mathrm{IsdB}^{\mathrm{N} 1}$, we analyzed the effect of the linker domain on the structure of $\mathrm{IsdB}^{\mathrm{N} 1}$ using NMR. Analysis of the $2 \mathrm{D}{ }^{1} \mathrm{H}-{ }^{15} \mathrm{~N}$ HSQC NMR data of the ${ }^{15} \mathrm{~N}$-labeled IsdB ${ }^{\mathrm{N} 1-\mathrm{L}}$ protein relative to $\mathrm{IsdB}^{\mathrm{N} 1}$ showed no observable changes in the $\mathrm{N} 1$ resonances in $\mathrm{IsdB}^{\mathrm{N} 1-\mathrm{L}}$, implying little interactions take place between linker and the N1 domain at least in solution in the absence of metHb (see Supporting Information Figure S2).

\section{DISCUSSION}

In this study, we report the $3 \mathrm{D}$ solution NMR structure of the first NEAT domain of IsdB, IsdB ${ }^{\mathrm{N} 1}$ spanning residues $125-270$ of the full-length native IsdB protein. Inspection of the structure reveals that $\mathrm{IsdB}^{\mathrm{N} 1}$ is comprised of a prototypical $\beta$ sheet rich immunoglobin-like fold similar to the ones observed for other NEAT domain-containing proteins solved to date.

A DALI-based structural alignment of Is $\mathrm{dB}^{\mathrm{N} 1}$, together with structural information obtained from other NEAT-domain containing proteins and structures reported in the PDB protein database, indicates that $\mathrm{IsdB}^{\mathrm{N} 1}$ is most structurally similar to the NEAT 1 and NEAT 2 domains of IsdH, referred to as $\mathrm{IsdH}^{\mathrm{N} 1}$ and $\mathrm{IsdH}^{\mathrm{N} 2}$. This similarity is not unexpected, since $\mathrm{IsdB}^{\mathrm{N} 1}$ shares $46 \%$ and $65 \%$ amino acid sequence identity with $\mathrm{IsdH}^{\mathrm{N} 1}$ and $\mathrm{IsdH}^{\mathrm{N} 2}$, respectively. As mentioned, most of the $\left({ }^{1} \mathrm{H},{ }^{15} \mathrm{~N}\right.$, ${ }^{13} \mathrm{C}$ ) NMR resonance signals originating from Is $\mathrm{dB}^{\mathrm{N} 1}$ could be assigned to specific amino acids except for one large contiguous stretch of residues located within the loop 2 region of $\mathrm{IsdB}^{\mathrm{N1}}$ including four aromatic residues $\left(\mathrm{F}_{164} \mathrm{Y}_{165} \mathrm{H}_{166} \mathrm{Y}_{167}\right)$ that, based on our structural analysis and recent mutational studies, are critical for $\mathrm{IsdB}^{\mathrm{N} 1}$ binding to $\mathrm{Hb}$. Interestingly, a similar difficulty with NMR resonance assignments was reported for corresponding IsdH ${ }^{\mathrm{N} 1}$ residues $\left(\mathrm{Y}_{125}, \mathrm{Y}_{126} \mathrm{H}_{127} \mathrm{~F}_{128}\right)$ in the solution NMR structure of free $\mathrm{IsdH}^{\mathrm{N} 1}$. . The lack of observable NMR signals for the four aromatic residues $\left(\mathrm{F}_{164} \mathrm{Y}_{165} \mathrm{H}_{166} \mathrm{Y}_{167}\right)$ of IsdB ${ }^{\mathrm{N1}}$ likely results from substantial line broadening in the NMR spectrum which is most likely due to chemical exchange on an intermediate $(\mathrm{ms})$ time scale, reflecting the intrinsic flexibility of L2 residues in the unbound solution state of Is $\mathrm{dB}^{\mathrm{N} 1}$, similar to its homologue $\mathrm{IsdH}^{\mathrm{N} 1}$.

Recent studies investigating the importance of aromatic residues within $\mathrm{L} 2$ have shown that they are critical for generating high affinity interactions between $\mathrm{IsdB}$, or $\mathrm{IsdH}^{\mathrm{N} 1}$ and $\mathrm{IsdH}^{\mathrm{N} 2}$, and $\mathrm{Hb} .9,17,42,43$ Experiments in which either single or multiple residues within the $\mathrm{L} 2$ aromatic region were substituted resulted in a several fold decrease in $\mathrm{Hb}$ binding, loss of $\mathrm{Hb}$ binding to $\mathrm{S}$. aureus cells, or a significant decrease in the rate of in vitro heme transfer from metHb to $\mathrm{IsdB}^{43}$ Interestingly, in the crystal structures of $\mathrm{IsdH}^{\mathrm{N} 1}: \operatorname{metHb}$ and $\mathrm{IsdH}^{\mathrm{N} 2 \mathrm{LN} 3}$ :metHb protein complexes, these aromatic residues adopt a well folded $\alpha$-helical structure and interact with amino acids of the A chain $\alpha$-helix of metHb. ${ }^{17,40}$ The crystal structures of these protein complexes also reveal that different aromatic residues within this "aromatic motif" participate in formation of the Hb-binding interface of $\mathrm{IsdH}^{40}$ The relatively high degree of flexibility within the L2 region may be a prerequisite for specific $\mathrm{Hb}$ binding to IsdB ${ }^{\mathrm{N} 1}$, supporting a "folding upon binding" model which is often observed for intrinsically disordered regions of proteins, ${ }^{44,45}$ and the plasticity of Hb-binding NEAT domain architectures. However, despite this flexibility, the particular nature of the aromatic residues within the aromatic motif of $\mathrm{IsdB}^{\mathrm{N} 1}$, Is $\mathrm{dH}^{\mathrm{N} 2}$, and $\mathrm{IsdH}^{\mathrm{N} 1}$ seems to be specific to each $\mathrm{Hb}$-binding NEAT domain, as swapping the aromatic motif of $\mathrm{IsdH}^{\mathrm{N} 1}$ for that of $\mathrm{IsdB}^{\mathrm{N1}}$ resulted in the inability of $S$. aureus cells to bind to $\mathrm{Hb}^{43}$ Further, engineering of an IsdB ${ }^{\mathrm{N} 1 \mathrm{LN} 2}$ chimeric protein construct in which the $\mathrm{IsdB}^{\mathrm{N} 1}$ domain is modified to include the aromatic residues of $\mathrm{IsdH}^{\mathrm{N} 1}$ can no longer rapidly transfer heme from metHb to IsdB. ${ }^{43}$ These data thus demonstrate that the amino acid context surrounding the L2 aromatic residues is necessary to promote tight $\mathrm{Hb}$ binding and rapid heme capture from metHb to IsdB. The specific molecular context around the aromatic motif of $\mathrm{IsdB}^{\mathrm{N} 1}$ and $\mathrm{IsdH}^{\mathrm{N} 1}$ may be the basis for the weaker affinity of $\mathrm{IsdB}^{\mathrm{N} 1}$ for metHb ( $K_{\mathrm{d}}$ is estimated in the micromolar range in this study) compared to $\mathrm{IsdH}^{\mathrm{N1}}\left(K_{\mathrm{d}}\right.$ has been reported to be $\sim 20 \mathrm{nM}$ for wild type $\mathrm{IsdH}^{\mathrm{N1}}$ as measured by SPR in ref 4).

In contrast to the IsdH $\mathrm{H}^{\mathrm{N} 1}$ and $\mathrm{IsdH}^{\mathrm{N} 2}$ domains that can form high affinity complexes with metHb, ${ }^{9,17} \mathrm{IsdB}^{\mathrm{N} 1}$ appears to bind metHb very weakly. Only in the presence of millimolar concentrations of $\mathrm{IsdB}^{\mathrm{N} 1}$ and metHb were interactions between the two proteins observable when studied by NMR. This result is consistent with a recent study by Bowden et al. ${ }^{42}$ which demonstrates that immobilized metHb on nickel beads was unsuccessful at pulling down a single domain of $\mathrm{IsdB}^{\mathrm{N} 1}$ (residues 126-270) or $\mathrm{IsdB}^{\mathrm{N} 1-\mathrm{L}}$ (residues 126-336) in pull down assays, whereas a high affinity (nanomolar) interaction with metHb could only be observed when both IsdB NEAT domains and the intervening linker are present and contiguous. ${ }^{42}$ We observed that addition of the linker region is needed to observe complex formation by gel filtration analysis, indicating that the linker domain further increases the affinity of IsdB ${ }^{\mathrm{N} 1}$ for metHb. How the linker imparts this effect is, however, unclear. In the Isd $\mathrm{H}^{\mathrm{N} 2 \mathrm{LN} 3}$ :metHb crystal structure, there are no obvious protein-protein interaction sites between the linker region and $\mathrm{Hb}$. We also checked using NMR to see if addition of the linker region changed the $\mathrm{N} 1$ domain structure.

Analysis of the 2D ${ }^{1} \mathrm{H}-{ }^{15} \mathrm{~N}$ HSQC NMR data of ${ }^{15} \mathrm{~N}$-labeled Is $\mathrm{dB}^{\mathrm{N} 1-\mathrm{L}}$ versus $\mathrm{IsdB}^{\mathrm{N} 1}$ proteins indicated that little if any interaction takes place between linker and the N1 domain. This observation was also made for IsdH $\mathrm{H}^{\mathrm{N} 2 \mathrm{LN} 3}$. In fact, based on the NMR titration data, it would appear that the very C-terminal residues extending from the N1 domain (residues Thr269Asp272) act as a hinge point within the IsdB multidomain structure. Support for this observation is further gathered by examination of the crystal structure of $\mathrm{IsdH}^{\mathrm{N} 2 \mathrm{LN} 3}$ in complex with metHb whereby comparable residues are not observed in the electron density map, ${ }^{40}$ suggesting that the equivalent $\mathrm{IsdH}$ linker residues remain flexible even upon binding to $\mathrm{Hb}$. Linker 
protein interactions thus appear to be an independent function separate from the $\mathrm{N} 1$ domain.

In the NMR titration study with ${ }^{15} \mathrm{~N}-\mathrm{IsdB}^{\mathrm{N} 1}$ and metHb, attempts to identify specific amides interacting with metHb via identification of ${ }^{1} \mathrm{H} /{ }^{15} \mathrm{~N}$ amide chemical shift perturbations proved unsuccessful, due to the significant line broadening taking place in the $2 \mathrm{D}{ }^{1} \mathrm{H}-{ }^{15} \mathrm{~N}$ HSQC NMR spectrum of the ${ }^{15} \mathrm{~N}-\mathrm{IsdB}^{\mathrm{N1}}$ :metHb complex. This uniform broadening of NMR resonances happened quickly upon mixing of the two proteins, and only resonances from the very $\mathrm{C}$-terminal residues (residues Thr269-Asp272) remained visible. The NMR titration data did, however, indicate that the $\mathrm{IsdB}^{\mathrm{N} 1}$ protein appears to preferentially interact with metHb at a $1: 1$ ratio. At an equal molar ratio of ${ }^{15} \mathrm{~N}-\mathrm{IsdB}^{\mathrm{N} 1}$ :metHb (expressed in $\alpha / \beta$ metHb dimeric units) near complete line broadening of the resonance was observed. At $\mathrm{IsdB}^{\mathrm{N} 1}:$ metHb ratios exceeding this, NMR resonance signals (indicative of free $\mathrm{IsdB}^{\mathrm{N} 1}$ ) reappeared. Previous binding studies on IsdH-N1 and -N2 have shown that each IsdH domain displays a higher binding affinity for the $\alpha$-subunits versus $\beta$-subunits of metHb, and SEC analysis herein showed that IsdH-N1 and -N2 domains preferentially bind only one metHb subunit. Therefore, $\mathrm{IsdB}^{\mathrm{N} 1}$ may be binding in a similar manner, with specificity preference for the $\alpha$-subunits of $\mathrm{Hb}$. It is important to note that the Clubb's laboratory has also shown clearly by both gel filtration and sedimentation equilibrium analysis that IsdH-N1/ $\mathrm{N} 2$ domains can bind both $\alpha$ and $\beta$ subunits, and that the binding of all four $\mathrm{Hb}$ subunits is clearly evident in the crystal structures of $\mathrm{IsdH}^{\mathrm{N} 2}$ and $\mathrm{IsdH}^{\mathrm{N} 2 / \mathrm{N} 3}$ with metHb. ${ }^{17,40}$ Full length IsdB must also bind to both the $\alpha$ and $\beta$ subunits of $\mathrm{Hb}$, as IsdB can get about $70 \%$ of metHb heme in a single phase kinetics process ${ }^{3}$ (Zhu et al., manuscript under review).

Extensive studies aimed at identifying specific IsdB/H residues that interact with $\mathrm{Hb}$ have focused on the conserved aromatic residues within loop 2, a structural "aromatic motif" which appears to be only present in the Hb-binding NEAT domains. Pishchany et al. ${ }^{43}$ demonstrated that mutation of any of these residues within $\mathrm{Is} \mathrm{dB}$ abrogated $\mathrm{Hb}$ binding to $\mathrm{S}$. aureus cells and slowed heme transfer between metHb and IsdB ${ }^{\mathrm{N} 1-\mathrm{L}-\mathrm{N} 2}$. Consistent with this data, our NMR and kinetic analysis results demonstrate that F164 is indeed critical for $\mathrm{IsdB}^{\mathrm{N} 1}$ binding to metHb and IsdB ${ }^{\mathrm{N} 1-\mathrm{L}-\mathrm{N} 2}$ 's ability to rapidly extract heme from metHb and to a lesser extent Y167. The fact that heme transfer can still occur with each amino acid substitution is consistent with previous observations ${ }^{43}$ that although residues within the Hb-binding "aromatic motif" site are important for IsdB and IsdH binding metHb, other residues within IsdH-N1 and -N2 and IsdB-N1 domains are also important for mediating IsdB/ metHb protein-protein interactions. Analysis of our docked model of $\mathrm{IsdB}^{\mathrm{N} 1}$ to metHb suggests that residues within the loops spanning $\beta 1 \mathrm{~b}$ and $\beta 2, \beta 7$ and $\beta 8$, and $\beta 3$ and $\beta 4$ are poised to make subtle contacts with metHb. Similar interaction sites are also observed for IsdH-N1 and -N2, and a comparison of IsdH and IsdB reveals no obvious differences as to why Is $\mathrm{dH}^{\mathrm{N} 1}$ and IsdH ${ }^{\mathrm{N} 2}$ domains have a high binding affinity for metHb whereas $\mathrm{IsdB}^{\mathrm{N1}}$, s affinity for metHb is lower.

Our heme transfer studies have revealed that a contiguous Is $\mathrm{dB}^{\mathrm{N} 1-\mathrm{L}-\mathrm{N} 2}$ is needed for rapid transfer rates consistent with other recently reported results. Interestingly, Bowden et al. ${ }^{42}$ have showed that an $\mathrm{IsdB}^{\mathrm{N} 1-\mathrm{L}}+\mathrm{IsdB}^{\mathrm{N} 2}$ construct could also rapidly transfer heme in vitro, suggesting that the IsdB linker region may also play a role in metHb binding. We have observed a similar effect. This increase in heme transfer function appears to be in stark contrast to IsdH where an $\mathrm{IsdH}^{\mathrm{N} 2-\mathrm{L}}+\mathrm{IsdH}^{\mathrm{N} 3} /$ metHb mixture resulted in only a negligible increase in heme transfer rate compared to N3 alone. Thus, although IsdH and IsdB appear to function similarly with respect to heme binding, the molecular mechanism of Is $\mathrm{dB}$ heme capture from metHb appears to be subtly but significantly different from that of IsdH. Further, our engineered $\mathrm{IsdB}^{\mathrm{N1}(\mathrm{F} 164 \mathrm{D}, \mathrm{Y167D})}$ double mutant constructs still displayed a faster heme transfer rate than the apparent rate of heme dissociation (off rate) from metHb. Heme transfer experiments using IsdB $\mathrm{I}^{\mathrm{L}-\mathrm{N} 2}$ constructs of various linker length (Figure $7 \mathrm{~B}$ ) suggest that residues within Is $\mathrm{dB}$ linker region that are interacting with $\mathrm{Hb}$ and thereby contributing to an enhanced rate of heme transfer from met- $\mathrm{Hb}$ must reside within the $\mathrm{N}$ terminal half of the linker domain as neither the 20L-N2 or $35 \mathrm{~L}-\mathrm{N} 2$ construct rescues the heme transfer effect of IsdB $\mathrm{B}^{\mathrm{L}-\mathrm{N} 2}$ (see Figure 7B). No high-resolution structure has been reported for IsdB linker domain. However, IsdB linker shares $70 \%$ sequence identity to the IsdH linker region, which has been shown to adopt a three-helix bundle structure in solution. ${ }^{46} \mathrm{CD}$ spectroscopy indicates that Is $\mathrm{dB}$ linker has propensity to form $\alpha$-helical structure. Thus, based on sequence similarity and $\mathrm{CD}$ data, one would expect the linker structures of IsdB and IsdH to be similar if not identical. However, NMR studies of IsdB linker in our laboratory do not support this expectation. There appears to be no obvious "direct" interactions of Isd $\mathrm{H}$ linker region with $\mathrm{Hb}$ that could provide a rationale for the enhanced heme transfer effect observed, yet clearly the N1-linker region of IsdB must be imparting a certain degree of structural strain on $\mathrm{Hb}$ to facilitate heme release and/ or to increase the rate of heme dissociation from $\mathrm{Hb}$ upon complex formation with IsdB. In the crystal structure of IsdH ${ }^{\text {N1LN2 }}$ with metHb, no obvious structural changes are observed for metHb upon binding to $\mathrm{IsdH}^{40}$ Thus, the molecular mechanism by which IsdB linker region enhances heme capture and transfer from metHb remains to be established. It is possible that determination of a $3 \mathrm{D}$ structure of IsdB ${ }^{\mathrm{N} 1 \mathrm{LN} 2}$ could reveal important structural changes within IsdB linker domain that could explain its effect on heme transfer from metHb.

In summary, we have solved the $3 \mathrm{D}$ solution NMR structure of the hemoglobin-binding NEAT domain of Is $\mathrm{dB}$, Is $\mathrm{dB}^{\mathrm{N} 1}$, encompassing IsdB residues $125-270$. We report that $\mathrm{IsdB}^{\mathrm{N} 1}$ adopts a canonical immunoglobin-like fold, similar to that of other NEAT domains and displays greatest structural similarity to NEAT 1 and 2 domains of IsdH, a closely related $\mathrm{Hb}$ / Haptoglobin-Hb receptor. ${ }^{9,17,40}$ The functional importance of two aromatic residues, F164 and Y167 within a conserved stretch of aromatic residues has been investigated and shown to be important for IsdB binding to $\mathrm{Hb}$. We find that F164 is critical for Is $\mathrm{dB}^{\mathrm{N} 1}$ binding to $\mathrm{Hb}$ and for an $\mathrm{IsdB}^{\mathrm{N} 1 \mathrm{LN} 2}$ protein to acquire heme from $\mathrm{Hb}$ efficiently, whereas residue Y167 appears more resilient to amino acid substitution. Finally, we demonstrate that the IsdB linker region increases the rate of heme transfer between metHb and $\mathrm{IsdB}^{\mathrm{N} 2}$ in vitro, and that this functional difference appears to be a result of an increase in the affinity of IsdB-N1 domain for metHb via interactions of IsdB linker domain with metHb. Together, these results show that it is the covalent and synergistic actions of all three domains N1L-N2 of IsdB that are necessary to facilitate rapid heme transfer between metHb and IsdB. 


\section{ASSOCIATED CONTENT}

\section{S Supporting Information}

Supplementary Figures S1 and S2 depicting the $2 \mathrm{D}{ }^{1} \mathrm{H}-{ }^{15} \mathrm{~N}$ HSQC NMR spectra of ${ }^{15} \mathrm{~N}-\mathrm{IdB}^{\mathrm{N} 1}$ :apo-metHb and ${ }^{15} \mathrm{~N}$-labeled Is $\mathrm{dB}^{\mathrm{N} 1-\mathrm{L}}$, respectively. This material is available free of charge via the Internet at http://pubs.acs.org.

\section{AUTHOR INFORMATION}

\section{Corresponding Author}

* Mailing address: Montana State University, Department of Chemistry \& Biochemistry, CBB 111A, Bozeman, MT 597173400. Phone: 406-994-7244. Fax: 406-994-5407. E-mail: vcopie@chemistry.montana.edu.

\section{Author Contributions}

${ }^{\S}$ B.A.F. and B.P.T. contributed equally to the work presented.

\section{Funding}

This work was funded in part by NIH Grants AI095704 and AI097703 from the National Institute of Allergy and Infectious Diseases, and GM103500-09 from the National Institute of General Medical Sciences, and the MSU's Center for the Analysis of Cellular Mechanisms and Systems Biology (NIH P20 GM 104935-06A1).

\section{Notes}

The authors declare no competing financial interest.

\section{ACKNOWLEDGMENTS}

The NMR experiments were recorded at Montana State University on a DRX600 Bruker solution NMR spectrometer, purchased in part with funds from the NIH Shared Instrumentation Grant (SIG) (Grant Number 1S10RR13878-01), and recently upgraded to an AVANCE III console and cryogenically cooled TCI probe (Grant Number 1S10-RR026659-01). We thank the Research Experience for Undergraduates (REU) program from the Department of Chemistry and Biochemistry (funded through NSF Grant 1156855) for support of REU undergraduate student R.M., and MSU's Emerging Scholar program for support of undergraduate student R.K.S.-S.

\section{REFERENCES}

(1) Casey, A. L., Lambert, P. A., and Elliott, T. S. J. (2007) Staphylococci. Int. J. Antimicrob. Agents 29, S23-S32.

(2) Weinberg, E. D. (1974) Iron and susceptibility to infectious disease. Science 184, 952-956.

(3) Zhu, H., Xie, G., Liu, M. Y., Olson, J. S., Fabian, M., Dooley, D. M., and Lei, B. F. (2008) Pathway for heme uptake from human methemoglobin by the iron-regulated surface determinants system of Staphylococcus aureus. J. Biol. Chem. 283, 18450-18460.

(4) Pilpa, R. M., Robson, S. A., Villareal, V. A., Wong, M. L., Phillips, M., and Clubb, R. T. (2009) Functionally Distinct NEAT (NEAr Transporter) Domains within the Staphylococcus aureus IsdH/HarA Protein Extract Heme from Methemoglobin. J. Biol. Chem. 284, 11661176

(5) Moriwaki, Y., Rearad, T., Caaveiro, J. M. M., Takaoka, Y., Hamachi, I., Tsumoto, K., and Shimizu, K. (2013) Heme binding mechanism of structurally similar iron-regulated surface determinant near transporter domains of Staphylococcus aureus exhibiting different affinities for heme. Biochemistry 52, 8866-8877.

(6) Maresso, A. W., and Schneewind, O. (2006) Iron acquisition and transport in Staphylococcus aureus. Biometals 19, 193-203.

(7) Skaar, E. P., and Schneewind, O. (2004) Iron-regulated surface determinants (Isd) of Staphylococcus aureus: stealing iron from heme. Microbes Infect. 6, 390-397.
(8) Andrade, M. A., Ciccarelli, F. D., Perez-Iratxeta, C., and Bork, P. (2002) NEAT: a domain duplicated in genes near the components of a putative Fe3+ siderophore transporter from Gram-positive pathogenic bacteria. Genome Biol. 3, 0047.0041 DOI: 10.1186/gb-2002-3-9research0047.

(9) Pilpa, R. M., Fadeev, E. A., Villareal, V. A., Wong, M. L., Phillips, M., and Clubb, R. T. (2006) Solution structure of the NEAT (NEAr Transporter) domain from IsdH/HarA: The human hemoglobin receptor in Staphylococcus aureus. J. Mol. Biol. 360, 435-447.

(10) Grigg, J. C., Vermeiren, C. L., Heinrichs, D. E., and Murphy, M. E. P. (2007) Haem recognition by a Staphylococcus aureus NEAT domain. Mol. Microbiol. 63, 139-149.

(11) Sharp, K. H., Schneider, S., Cockayne, A., and Paoli, M. (2007) Crystal structure of the heme-IsdC complex, the central conduit of the isd iron/heme uptake system in Staphylococcus aureus. J. Biol. Chem. 282, 10625-10631.

(12) Watanabe, M., Tanaka, Y., Suenaga, A., Kuroda, M., Yao, M., Watanabe, N., Arisaka, F., Ohta, T., Tanaka, I., and Tsumoto, K. (2008) Structural basis for multimeric heme complexation through a specific protein-heme interaction - The case of the third neat domain of IsdH from Staphylococcus aureus. J. Biol. Chem. 283, 28649-28659.

(13) Villareal, V. A., Pilpa, R. M., Robson, S. A., Fadeev, E. A., and Clubb, R. T. (2008) The IsdC Protein from Staphylococcus aureus Uses a Flexible Binding Pocket to Capture Heme. J. Biol. Chem. 283, 31591-31600.

(14) Gaudin, C. F. M., Grigg, J. C., Arrieta, A. L., and Murphy, M. E. P. (2011) Unique Heme-Iron Coordination by the Hemoglobin Receptor IsdB of Staphylococcus aureus. Biochemistry 50, 5443-5452.

(15) Grigg, J. C., Ukpabi, G., Gaudin, C. F. M., and Murphy, M. E. P. (2010) Structural biology of heme binding in the Staphylococcus aureus Isd system. J. Inorg. Chem. 104, 341-348.

(16) Grigg, J. C., Mao, C. X., and Murphy, M. E. P. (2011) IronCoordinating Tyrosine Is a Key Determinant of NEAT Domain Heme Transfer. J. Mol. Biol. 413, 684-698.

(17) Kumar, K. K., Jacques, D. A., Pishchany, G., Caradoc-Davies, T., Spirig, T., Malmirchegini, G. R., Langley, D. B., Dickson, C. F., Mackay, J. P., Clubb, R. T., Skaar, E. P., Guss, J. M., and Gell, D. A. (2011) Structural Basis for Hemoglobin Capture by Staphylococcus aureus Cell-surface Protein, IsdH. J. Biol. Chem. 286, 38439-38447.

(18) Torres, V. J., Pishchany, G., Humayun, M., Schneewind, O., and Skaar, E. P. (2006) Staphylococcus aureus IsdB is a hemoglobin receptor required for heme iron utilization. J. Bacteriol. 188, 84218429.

(19) Muryoi, N., Tiedmann, M. T., Pluym, M., Cheung, J., Heinrichs, D. E., and Stillman, M. J. (2008) Demonstration of the iron-regulated surface determinant (Isd) heme transfer pathway in Staphylococcus aureus. J. Biol. Chem. 283, 28125-28136.

(20) Kim, H. K., DeDent, A., Cheng, A. G., McAdow, M., Bagnoli, F., Missiakas, D. M., and Schneewind, O. (2010) IsdA and IsdB antibodies protect mice against Staphylococcus aureus abscess formation and lethal challenge. Vaccine 28, 6382-6392.

(21) Fonner, B. A., Tripet, B. P., Liu, M., Zhu, H., Lei, B., and Copié, V. (2014) ${ }^{1} \mathrm{H},{ }^{13} \mathrm{C},{ }^{15} \mathrm{~N}$ backbone and side chain NMR resonance assignments of the $\mathrm{N}$-terminal $\mathrm{NEAr}$ iron transporter domain 1 (NEAT 1) of the hemoglobin receptor IsdB of Staphylococcus aureus. Biomol. NMR Assignments 8, 201-205.

(22) Bodenhausen, G., and Ruben, D. J. (1980) Natural abundance nitrogen-15 NMR by enhanced heteronuclear spectroscopy. Chem. Phys. Lett. 69, 185-189.

(23) Hwang, T. L., and Shaka, A. J. (1998) Multiple-pulse mixing sequences that selectively enhance chemical exchange or crossrelaxation peaks in high-resolution NMR spectra. J. Magn. Reson. $135,280-287$.

(24) Delaglio, F., Grzesiek, S., Vuister, G. W., Zhu, G., Pfeifer, J., and Bax, A. (1995) NMRPipe- a Multidimensional Spectral Processing System Based on Unix Pipes. J. Biomol. NMR 6, 277-293.

(25) Goddard, T. D., and Kneller, D. G. (2008) SPARKY 3, University of California, San Francisco. 
(26) Herrmann, T., Guntert, P., and Wuthrich, K. (2002) Protein NMR structure determination with automated NOE-identification in the NOESY spectra using the new software ATNOS. J. Biomol. NMR 24, 171-189.

(27) Herrmann, T., Guntert, P., and Wuthrich, K. (2002) Protein NMR structure determination with automated NOE assignment using the new software CANDID and the torsion angle dynamics algorithm DYANA. J. Mol. Biol. 319, 209-227.

(28) Shen, Y., Delaglio, F., Cornilescu, G., and Bax, A. (2009) TALOS plus: a hybrid method for predicting protein backbone torsion angles from NMR chemical shifts. J. Biomol. NMR 44, 213-223.

(29) Guntert, P., Mumenthaler, C., and Wuthrich, K. (1997) Torsion angle dynamics for NMR structure calculation with the new program DYANA. J. Mol. Biol. 273, 283-298.

(30) Case, D. A., Darden, T. A., Cheatham, I., T, E., Simmerling, C. L., Wang, J., Duke, R. E., Luo, R., Merz, K. M., Pearlman, D. A., Crowley, M., Walker, R. C., Zhang, W., Wang, B., Hayik, S., Roitberg, A., Seabra, G., Wong, K. F., Paesani, F., Wu, X., Brozell, S., Tsui, V., Gohlke, H., Yang, L., Tan, C., Mongan, J., Hornak, V., Cui, G., Beroza, P., Mathews, D. H., Schafmeister, C., Ross, W. S., and Kollman, P. A. (2006) AMBER 9, University of California, San Francisco.

(31) Bertini, I., Case, D. A., Ferella, L., Giachetti, A., and Rosato, A. (2011) A Grid-enabled web portal for NMR structure refinement with AMBER. Bioinformatics 27, 2384-2390.

(32) Laskowski, R. A., Rullmann, J. A. C., MacArthur, M. W., Kaptein, R, and Thornton, J. M. (1996) AQUA and PROCHECKNMR: Programs for checking the quality of protein structures solved by NMR. J. Biomol. NMR 8, 477-486.

(33) Chen, V. B., Arendall, W. B., Headd, J. J., Keedy, D. A. Immormino, R. M., Kapral, G. J., Murray, L. W., Richardson, J. S., and Richardson, D. C. (2010) MolProbity: all-atom structure validation for macromolecular crystallography. Acta Crystallogr., Sect. D 66, 12-21.

(34) Luthy, R., Bowie, J. U., and Eisenberg, D. (1992) Assessment of Protein Models with 3-Dimensional Profiles. Nature 356, 83-85.

(35) Bhattacharya, A., Tejreo, R., and Montelione, G. T. (2007) Evaluating Protein Structures Determined by Structural Genomics Consortia. Proteins 66, 778-795.

(36) DeLano, W. L. (2002) The PyMol Molecular Graphics System, DeLano Scientific, San Carlos, CA.

(37) Holm, L., and Rosenstrom, P. (2010) Dali server: conservation mapping in 3D. Nucleic Acids Res. 38, W545-W549.

(38) Emsley, P., Lohkamp, B., Scott, W. G., and Cowtan, K. (2010) Features and development of Coot. Acta Crystallogr., Sect. A D66, 486-501.

(39) Ascoli, F., Fanelli, M. R., and Antonini, E. (1981) Preparation and properties of apo-hemoglobin and reconstituted hemoglobins. Methods Enzymol. 76, 72-87.

(40) Dickson, C. F., Kumar, K. K., Jacques, D. A., Malmirchegini, G. R., Spirig, T., Mackay, J. P., Clubb, R. T., Guss, J. M., and Gell, D. A. (2014) Structure of the hemoglobin-IsdH complex reveals the molecular basis of iron capture by Staphylococcus aureus. J. Biol. Chem. 289, 6728-6738.

(41) Schlenker, C., Goel, A., Tripet, B. P., Menon, S., Willi, T., Dlakic, M., Young, M. J., Lawrence, C. M., and Copie, V. (2012) Structural Studies of E73 from a Hyperthermophilic Archaeal Virus Identify the "RH3" Domain, an Elaborated Ribbon-Helix-Helix Motif Involved in DNA Recognition. Biochemistry 51, 2899-2910.

(42) Bowden, C. F. M., Verstraete, M. M., Eltis, L. D., and Murphy, M. E. P. (2014) Hemoglobin binding and catalytic heme extraction by IsdB near iron transporter domains. Biochemistry 53, 2286-2294.

(43) Pishchany, G., Sheldon, J. R., Dickson, C. F., Alam, T., Read, T. D., Gell, G. A., Heinrichs, D. E., and Skaar, E. P. (2014) IsdBdependent hemoglobin binding is required for acquisition of heme by Staphylococcus aureus. J. Infect. Dis. 209, 1764-1772.

(44) Hazy, E., and Tompa, P. (2009) Limitations of induced folding in molecular recognition by intrinsically disordered proteins. ChemPhysChem 10, 1415-1419.

(45) Uversky, V. (2013) Unusual biophysics of intrinsically disordered proteins. Biochim. Biophys. Acta 1834, 932-951.
(46) Spirig, T., Malmirchegini, G. R., Zhang, J., Robson, S. A., Sjodt, M., Liu, M. Y., Kumar, K. K., Dickson, C. F., Gell, D. A., Lei, B. F., Loo, J. A., and Clubb, R. T. (2013) Staphylococcus aureus Uses a Novel Multidomain Receptor to Break Apart Human Hemoglobin and Steal Its Heme. J. Biol. Chem. 288, 1065-1078. 